\title{
A invenção como ofício: as máquinas de preparo e benefício do café no século XIX'
}

\section{Luiz Cláudio M. Ribeiro²}

RESUMO: Aborda-se a sociedade cafeeira brasileira sob o aspecto da geração de invenções e inovações de máquinas destinadas ao preparo e benefício do café no período de 1860 a 1882. Sob a proteção da Lei de Patentes de 1830, os machinistas desenvolviam seus inventos, que eram examinados pela Sociedade Auxiliadora da Indústria Nacional (SAIN) para concessão do privilégio industrial e posterior fabricação e comercialização. Demonstrase como as máquinas de café desenvolvidas por estes inventores-empresários no Brasil trouxeram para a fazenda cafeeira escravista a atualização tecnológica de máquinas agrícolas existentes nos países industriais e propiciaram uma melhoria de qualidade do benefício em grandes quantidades de café. Tal fato tornou possível não só a consolidação do país como maior exportador no mercado internacional, mas permitiu alterações na estrutura produtiva das fazendas escravistas.

PALAVRAS-ChAVE: Café. Beneficiamento de café. Máquinas de café. Economia cafeeria. Patentes.

ABSTRACT: The article studies the Brazilian coffee-growing society from the point of view of the generation of inventions and machine innovations aimed at the preparation and processing of coffee beans in the period between 1860 and 1882. Under the protection of the 1830 Patents Law, the machinistas developed their inventions and submitted them to the National Industry Auxiliary Society (Sociedade Auxiliadora da Indústria Nacional - SAIN) for the concession of industrial privilege and later manufacture and commercialization. It is demonstrated how the coffee machinery developed by these inventors-entrepreneurs in Brazil brought to the slave-labour coffee plantation the technological update of agricultural machines existing in the industrial countries and how that has propitiated an improvement in the quality of large-scale coffee bean processing. This fact has made possible not only the consolidation of the country as the largest exporter in the international market, but has also has allowed for changes in the productive structure of the slave-labour plantations.

KEYWORDS: Coffee. Coffee bean processing. Coffee machines. Coffee economy. Patents.
1. Agradeço ao Arquivo Nacional-RJ pela cessão das imagens aqui inseridas. Este artigo foi escrito a partir de capítulo de minha dissertação de mestrado (RIBEIRO, 1995).

2. Docente do Centro de Ciências Humanas e Naturais da Universidade Federal do Espírito Santo (UFES). E-mail: lclaudio @npd.ufes.br 
....ao meio-dia, almoçai tranquilamente com os vossos. Às duas horas, parti em balão. Dez minutos mais tarde não sereis mais um cidadão vulgar, sim um explorador, um aventureiro da ciência.

Alberto Santos Dumont (1938, p. 90).

No transcorrer da primeira para a segunda metade do século XIX, O ocidente experimentou o potencial transformador da ciência aplicada ao trabalho das máquinas. As distâncias eram vencidas com menor esforço e cargas cada vez maiores viajavam por trilhos ou em embarcações pelo mundo. Na Europa, a vida urbana se sobrepunha ao bucolismo, e as máquinas poupavam o trabalho braçal. Tudo isto ocorreu à medida que se desenvolveu a conversão do aço, a siderurgia, a utilização da energia elétrica, a construção das estradas de ferro, etc. $\bigcirc$ domínio de tantos conhecimentos científicos aplicados fez surgir o motor a combustão interna, o automóvel, o telefone, os bondes, os equipamentos elétricos, e tantos outros bens que alteraram o cotidiano das cidades em todo o mundo (KEMP, 1987).

Este incremento tecnológico não ocorreu de forma abrupta, mas foi resultado de aperfeiçoamentos lentamente alcançados pela pesquisa científica de cunho mais empírico, que desenvolveu novos processos e materiais industriais. Em 1850, a energia a vapor já era responsável pelo grosso da produção industrial inglesa e, nas décadas seguintes, teria importante desempenho na produção industrial de países como a Alemanha, a França e os Estados Unidos (HOBSBAWN, 1983).

Tratando-se de um tempo em que os objetos eram produzidos com materiais naturais - madeira, couro, pedra etc. - e com produtos pouco elaborados - o ferro fundido, o bronze e os vidros -, não admira que as pesadas máquinas industriais do século XIX fossem feitas de peças de madeira e metal. $\bigcirc$ automatismo desses maquinismos, fundamental à produção industrial em série, foi sendo aprimorado com motricidade independente dos fenômenos naturais. A capacidade e a especialização das máquinas obedeciam às necessidades específicas da produção. Tal demanda foi responsável pelo grande avanço tecnológico por que passaram seus componentes como engrenagens, polias, materiais de transmissão das correias, etc.

As comunidades científicas esmeravam-se em divulgar experiências bem sucedidas, e as que despertavam interesse comercial eram logo produzidas industrialmente. Desta forma, os governantes e empresários estavam convencidos que, através da ciência, o homem europeu "caminhava para o Olimpo", livrandose das amarras de Prometeu (LANDES, 1994). Um bom exemplo desta ambição foi a construção, na década de 1860, pelos confederados norte-americanos do submarino Hunley, de nove metros de comprimento, que atacava embarcações da União que bloqueavam os portos do sul. Feito no Alabama, o Hunley carregava 90 quilos de pólvora. Nele, nove homens se revezavam para o acionamento da manivela que o impulsionava a até 7,4 quilômetros por hora. $\bigcirc$ submarino era iluminado por um lampião, e sua forma de ataque consistia em posicionar- 
se sob as embarcações inimigas, explodindo-as, não sem antes se deslocar para longe dos alvos ${ }^{3}$.

A seu modo, o Brasil acompanhava o desenvolvimento científico, almejando granjear ingresso no mundo civilizado, ao lado da Inglaterra, da França, da Bélgica, da Alemanha e da "grande República" 4 . Na comunidade cientifica, a escravidão, a imigração, o regime monárquico e o desejo de promover a indústria agrícola eram temas acalorados na Sociedade Auxiliadora da Indústria Nacional (fundada em 1827), na Escola Polytechnica (1874) e no Clube de Engenharia (1880) (LOBO, 1989, p. 27-28). Mas o debate sobre a modernização agrícola espalhou-se, e foi por meio dele que intelectuais e engenheiros brasileiros exaltaram a modernidade, apreendida em visitas à Europa e aos EUA. A sociedade cafeeira do Sudeste também foi impregnada pelos novos valores desse mundo tecnológico (PESAVENTO, 1992).

No meio rural, os maiores fazendeiros brasileiros eram, em grande parte, homens acostumados às lides das campanhas políticas e do mundo dos negócios; portanto, pertencentes ao que julgavam ser o mundo civilizado. De fato, alguns centros urbanos já dispunham de invejável estrutura de ensino, como, por exemplo, a Campinas dos anos de 1860, como se observa pela descrição de Zaluar:

Existem aqui duas escolas públicas de primeiras letras, uma secundária e cinco particulares de instrução secundária, sendo uma de cada sexo; representando o número total dos alunos de todas essas aulas, do sexo masculino duzentos e quarenta e do feminino cento e vinte educandas. Além dessas casas de ensino a maior parte dos fazendeiros paga mestres para educar seus filhos, e um bom número de jovens campineiros freqüenta atualmente em São Paulo as aulas da Faculdade de Direito [...] lapud LIMA, 1986, p. 27).

mesmo ambiente cultural também marcava a cidade de Resende, quando os filhos dos fazendeiros estudavam na Corte ou na Europa e

[...] a elite intelectual, embora reduzida, buscava divulgar as novas idéias trazidas de fora através da imprensa. José Pereira Barreto, por exemplo, foi o introdutor em Resende do Catecismo do agricultor, de Burlamaque, um dos mais considerados manuais da agricultura da época. Sendo um dos articulistas do jornal O Itatiaia, procurava estimular a leitura de publicações especializadas que recebia dos Estados Unidos, como o Agriculturalist e o Scientific American. Seu irmão, Luís Pereira Barreto, formado em medicina e ciências naturais na Bélgica, na década de 1860, foi o responsável pela introdução do café tipo Bourbon no oeste paulista, espécie desenvolvida por ele a partir de suas experiências (WHATELY, 1987, p. 34-35).

No interior do país, as famílias ricas percebiam a engenharia como uma opção de carreira e enviavam seus filhos para as escolas mais afamadas da Europa. Foi este o caso dos Santos Dumont. Antes de completar 19 anos, o jovem Alberto receberia do pai três valiosos bens que orientariam definitivamente sua vida - a carta de maioridade, sua parte na herança familiar e o conselho para que seguisse para Paris em busca do "futuro do mundo": o conhecimento da mecânica (DUMONT, 1938).
3.Cf.notícia publicada no jornal $O$ Globo (p. 15, 15 jun. 1995), dando conta do resgate da embarcação na costa da Carolina do Sul, EUA, onde afundou em 1864.

4. André Rebouças, monarquista, assim se referiu aos Estados Unidos da América em seus artigos de análise da agricultura brasileira, reunidos em: REBOUCAS, André. Agricultura Nacional: estudos econômicos. Rio de Janeiro:Typographia A. J. Lamoreux, 1883. p. 27. 
5. Sobre a Exposição Universal da Philadelphia, em 1876, Nicolau J. Moreira afirmou "[...]que na União-Americana grande parte do café brasileiro superior era vendido sob diversas denominações sendo conhecido geralmente como produto do Brasil o café ordinário que aparecia no mercado; café dos pobres - tal era o nome que se lhe dava". (O AUXILIADOR, 1881.p 79). Grifo do autor.

6. Tratava-se da preparação do terreno para o plantio do cafezal, que era feita com a derrubada completa, seguida da queima de toda a cober tura vegetal primária, lar gamente utilizada pelos plantadores brasileiros (RIBEIRO, 1995)
Mas o Petit Santos levou, na bagagem pessoal, as lembranças do ranger dos mechanismos no trabalho, o conhecimento dos materiais e a criatividade. Ainda cedo, sua imaginação fora povoada pelas personagens de Júlio Verne e Phileas Fogg, que o conduziram ao universo técnico de então. De suas lembranças mais remotas, Dumont relatou que, aos três anos,

[...] Enquanto meu pai e meus irmãos montavam a cavalo para irem mais ou menos distante ver si os cafeeiros eram bem tratados, si a colheita ia bem ou si as chuvas causavam prejuízos, eu preferia fugir para a usina, para brincar com as máquinas de beneficiamento (DUMONT, 1938 , p. 491.

\section{E completou:}

[...] Todas essas máquinas de que acabo de falar, bem como as que forneciam a força motriz, foram os brinquedos da minha meninice. $\bigcirc$ hábito de vê-las funcionar diariamente ensinou-me muito depressa, a reparar qualquer das suas peças (DUMONT, 1938, p. 52).

A "brincadeira" da infância de Dumont era composta por máquinas de diferentes funções e graus diversos de aperfeiçoamento, utilizadas para o benefício do café na fazenda. Além das máquinas a vapor importadas, cujas caldeiras podiam ser fabricadas no Brasil, as demais eram construídas basicamente em madeira, com partes em metal, couro, vidro e outros materiais disponíveis, que sofreriam profundas modificações, a partir da década de 1870, à medida que se desenvolvia a indústria de materiais sintéticos e a siderurgia.

Ao mesmo tempo que o café passou a ser o principal produto exportável do Império, as técnicas de outros tempos ficaram incompatíveis com os novos padrões de consumo, no que dizia respeito tanto à qualidade quanto à quantidade de café produzido. Os grandes terreiros de secagem, os pilões manuais, os monjolos, os ripes e os carretões puxados por bois ficavam cada vez mais distantes das exigências de um produto capaz de disputar no mercado mundial com o chá, o chocolate, a chicória e outros gêneros de consumo popular 5 .

À medida que ocorria uma especialização da produção para exportação, os fazendeiros sentiam a necessidade de um novo padrão de beneficiamento, em contrapartida à cultura do café plantado pelo método de insolação e à exploração do escravo e do imigrante na lavoura. Por volta de 1860, ficava cada vez mais evidente a ausência, no Brasil, de um modo unificado de beneficiar o café. As técnicas e o tipo de machinismo empregado variavam de fazenda para fazenda e de região para região. A falta de padronização do benefício comprometia a qualidade do produto exportado, tendo sido o problema ainda mais agravado com a introdução de outras variedades da planta, como o libéria, bourbon, amarelo etc.

O objetivo dos fazendeiros, ao ocupar áreas nativas, era obter maiores lucros, aproveitando-se do mercado promissor que o café representava. Nesse caso, a utilização do escravo era não somente a melhor alternativa, mas condição para que o fazendeiro obtivesse empréstimos para o estabelecimento das fazendas e para o plantio dos novos cafezais. Para o fazendeiro de café, a 
terra era um bem secundário; o valor estava no cafezal plantado e na extensão de florestas a derrubar para o plantio.

Como é sabido, a derrubada e a queimada da floresta nativa expunham a lavoura às condições específicas de cada clima e de cada solo da floresta Atlântica. Isto exigia soluções diferenciadas segundo a situação, ou seja, o mesmo tipo de café, plantado em uma mesma época e com o mesmo método, poderia sofrer variações na qualidade de acordo com a região e a forma de cultivo e benefício. $\bigcirc$ resultado eram safras irregulares, tanto na qualidade como na quantidade, além de uma variedade de cafés dificilmente classificáveis e estandardizáveis.

Além de oferecer uma solução para tais problemas, as máquinas amenizavam a carência de braços cativos. Pode-se, então, dizer que a entrada da máquina no processo produtivo do café operou uma transformação na estrutura da fazenda cafeeira brasileira. Até aquele momento, as instalações de beneficiamento das fazendas conjugavam com a máquina a vapor os equipamentos mais rudimentares, o que demonstrava uma enorme disposição em aceitar de pronto as inovações tecnológicas importadas. Ilustrativo desse aspecto é o depoimento de von Tschudi, privilegiado observador do Brasil da década de 1860. Ao visitar a fazenda de um extraficante de escravos que se tornou cafeicultor, o viajante afirmou:

Antes do almoço mostrou-me o Comendador André seu estabelecimento, que me surpreendeu, tanto pela extensão, como pelas instalações e distribuição racional. Uma máquina a vapor movimentava ali, segundo as necessidades, ora uma prensa de açúcar, ora um monjolo de café, um moinho de milho ou uma serra circular (VON TSCHUDI, 1954, p. 16).

Von Tschudi observou como era possível, no Brasil, fazer-se o beneficiamento do café conjugando métodos antigos com outros mais modernos. Quando o café chegava na sede da fazenda "suas bagas eram submetidas a tratamento diverso". A primeira consideração que fez foi sobre o uso de água no beneficiamento. No caso do método a seco, havia

O mais simples e primitivo processo de separar a polpa da semente consiste em deixar as bagas no terreiro até que sequem. Do terreiro levam os grãos para o monjolo até onde se procede à descascagem dos grãos, e daí para a peneira, onde se completa a limpeza (VON TSCHUDI, 1954, p. 35-36).

Porém, em fazendas com aguadas abundantes e dirigidas à exportação ou venda,

Quando o tratamento é mais cuidadoso, as bagas são postas em grandes tinas com água para se tornarem mais moles, ou são passadas entre dois cilindros que, esmagando a polpa, a removem quase inteiramente. As sementes vão para um reservatório d'água para amolecer o resto da polpa, que é facilmente removida passadas algumas horas. Após isto, lavam-se os grãos em água limpa e estendem-nos no terreiro para secar. Uma vez secos, voltam a passar nuns cilindros mais finos, que removem os últimos filamentos da polpa, mas não ainda a casca de pergaminho. Depois de novo processo de secagem, ao sol ou por métodos 
artificiais, os grãos voltam ao monjolo, para remover-se a casca de pergaminho e, finalmente, vão para o moinho limpador ou peneira, que thes dá a limpeza final (VON TSCHUDI, 1954, p. 35-36).

\section{E conclui explicando que:}

Entre os métodos simples ou complicados há ainda muitas variedades, determinados pelo cuidado que o fazendeiro quer dispensar ao produto, pela sua inteligência, pelos recursos, etc. $\bigcirc$ café limpo é ensacado em sacas de 5 arrobas (de 32 libras), isto é 162 libras e levado ao mercado (VON TSCHUDI, 1954, p. 35-36).

As anotações de von Tschudi são importantes para caracterizar a conjugação da máquina a vapor com antigos equipamentos agrícolas, como o monjolo. A importação das últimas novidades tecnológicas surgidas fora do Brasil induziu, porém, no país, uma produção de novas máquinas agrícolas adaptadas à máquina a vapor.

Seria errôneo pensar que, na década de 1870, o monjolo fosse a única forma de beneficiamento de café; ou que a máquina a vapor fosse o único meio moderno utilizado nas fazendas. Desde a década anterior, muitos machinismos foram produzidos para utilizar o movimento da turbina fundida em metal ou feita em madeira. Isto otimizava o aproveitamento da energia hidráulica e possibilitava uma geração maior e mais uniforme de potência. Mesmo nos países industriais, essa modalidade de energia continuava sendo aproveitada nas fábricas e fazendas servidas por cursos abundantes de água (BLOCH, 1985). Por isso, quando os fazendeiros punham suas propriedades à venda, além da fertilidade das terras - associada à existência de matas nativas e à idade dos cafezais -, os recursos hídricos e as máquinas de beneficiar café eram colocados em primeiro plano, para comprovar o valor das propriedades.

Tal valorização demonstra a preocupação crescente dos fazendeiros de todas as regiões produtoras do Sudeste em introduzir, em suas fazendas, os novos equipamentos que surgiam. Observa-se, em relação ao padrão de beneficiamento descrito por von Tschudi, que houve um aumento do aproveitamento hidráulico, bem como a ampliação do uso da máquina a vapor, apesar do preço proibitivo para o pequeno e médio fazendeiro, enquanto outras máquinas específicas das fases de benefício de café foram introduzidas no processo de produção:

Vende-se duas fazendas perto de Campo Bello de Rezende a saber:

Uma que tem duzentos alqueires de terras, com mais de cem de matta-virgem, cafezaes, [...] muito boa água para todas as obras. Outra com grandes várzeas, terras muito boas para canna e mantimentos; tem cafezaes para mais de duas mil arrobas, tem um excellente engenho de socar café, moinho para descascar, ventilador, etc. tudo tocado por uma magnífica agua que dá para se collocar um machinismo de qualquer ordem [...] Igrifo do autorl? 
Uma outra fazenda posta à venda, dessa vez em Guaratinguetá (SP), era dotada de "[...] mato virgem, mais de 90.000 pés de café, sendo cerca de 75.000 de seis mezes, casas de vivendas, senzalas, paióes, moinho e engenho de café movidos por água, abanador e mais benfeitorias [...]" Igrifo do autor $)^{8}$.

Outro anúncio também é representativo da exigência daquele que pretendesse comprar uma fazenda de café:

Fazenda de café: precisa-se comprar uma fazenda nas seguintes condições: próxima a uma das estações da estrada de ferro, com lavoura para 4,000 a 5,000 arrobas de café, com trinta a quarenta escravos, todos os utensílios para o cultivo da mesma, engenho ou aguada sufficiente para construcção, terrenos bons, e alguma mata para novas lavouras, nunca menos de 50 alqueires de matto: quem a tiver nas condições e a desejar vender dirija-se à rua dos Beneditinos n. $27^{9}$.

E quais eram essas machinas e como eram utilizadas nas fazendas? Para melhor entendê-las, é preciso, antes, saber como se dava o beneficiamento do café.

$\bigcirc$ processo de cultivo e preparação do café para o consumo, no último quartel do século XIX, no Brasil, pode ser dividido em cinco fases definidas pelo uso de equipamentos no trato do cafeeiro e do seu fruto: agrícola, preparatória, beneficiamento, industrial e comercial.

Na primeira fase estão as ferramentas agrícolas - enxadas, foices, facões etc. -, as esteiras de colheita, as peneiras e os carrinhos de transporte. Na fase seguinte - preparatória -, estão os aparelhos lavadores, os classificadores, os despolpadores e os secadores que tratam do café no estado de cereja (maduro). As máquinas desta fase destinavam-se a lavar a sujeira dos grãos e a separar pedras, folhas e outras impurezas, fazer a classificação dos grãos por grau de maturação e por tamanho, retirar a casca e a polpa suculenta que envolve a semente, preparando-a para a fase seguinte, quando se dá a retirada da membrana que a envolve.

A fase de beneficiamento ou benefício inclui os descascadores, os ventiladores e os separadores. Nesta fase, entram em ação as máquinas que recebem o café coquinho (seco); são elas que retiram a fina membrana que envolve as duas partes da semente e insuflam ar para melhor secar os grãos e separá-los das membranas. A um só tempo, muitas máquinas faziam as três operações, cada uma cumprindo sua parte, e havia outras inovações que buscavam exatamente conjugar as etapas desta fase numa só machina, de forma a racionalizar a produção e diminuir seu custo. Tratava-se de uma demanda técnica a ser atendida.

Na fase industrial, estavam os brunidores e os ensacadores. Os brunidores eram máquinas que faziam o polimento do grão seco do café para realçar sua cor natural e deixá-lo atrativo ao olhar; após esta fase, o café era ensacado e empilhado em local seco, estando pronto para o transporte e para a torrefação. Algumas máquinas faziam sozinhas todas as operações das fases de benefício e industrial, como será visto. Na fase comercial, finalmente, 
10. " $[\ldots]$ compreende-se por 'benefício' a operação de descascar o café já seco, quer em coco, quer em pergaminho. Quando o produto se encontra recolhido às tulhas, depois do devido 'descanso' (cerca de 40 dias no mínimo) deve o lavrador aprestar-se para o seu benefício." (CAMARGO; TELLES JR. 1953, p. 496).

11. OJornal do Commercio (p. 6, 27 set. 1874) trouxe a mensagem: "para Valença: deseja-se comprar tres escravos carpinteiros ou marceneiros, que sejão possantes e de boa conducta, e não se faz questão de dinheiro [...]".

12. É comum encontrar nos jornais, principalmente a partir de 1880 anúncios como " $[\ldots]$ um homem casado, perito machinista, com muita prática de beneficiar café, deseja encontrar uma fazenda importante para tomar conta dos engenhos [...]" (Jornal do Commercio, Rio de Janeiro,p. 5, 15 jan. 1880). encontravam-se os torrefadores, os moinhos e as cafeteiras para a decocção do café.

O processo como um todo era chamado benefício ou beneficiamento do café $^{10}$ e consistia na eliminação sucessiva das camadas que envolvem as sementes do fruto, deixando-as em condição de serem torradas e moídas. Contudo, no período em questão, inexistia no Brasil qualquer padrão estabelecido de beneficiar o café. Em vista disso, havia uma polêmica entre os cafeicultores e as agências importadoras sobre os preços pagos e sobre a aceitação do produto no exterior.

Essas agências criticavam os métodos brasileiros de beneficiamento, responsabilizando-os pelo mau cheiro e pelo péssimo paladar. Sua maior queixa, do ponto de vista técnico, era a de que, na falta do secador mecânico, o café era deixado exposto ao sol no terreiro para secar e ventilar. Porém, quando havia chuvas ou muita umidade no ar, isso não ocorria, e a fermentação do produto por tempo demasiado acabava causando o apodrecimento da polpa antes que ela fosse retirada. Enquanto o café brasileiro era reexportado para mercados menos exigentes, já que considerado de qualidade inferior, outros produtores como Java, Ceilão, Costa Rica e México produziam café em menores quantidades, mas de qualidade superior, que era consumido nos principais centros europeus.

No Brasil, à medida que as fazendas se especializavam e eram servidas de máquinas inovadoras na preparação do café, a composição da força de trabalho também sofria alteração. Apesar de muitos escravos serem especializados em carpintaria, marcenaria, construção civil, enfermagem etc. "', os equipamentos de benefício exigiam pessoas habituadas à leitura de manuais e à compreensão de desenhos, e capazes, ainda, de procederem às adaptações técnicas necessárias. Tais exigências favoreceram o surgimento de machinistas, para a implantação e o funcionamento das novas instalações mecânicas ${ }^{12}$.

Tais profissionais - entre eles até mesmo alguns fazendeiros desenvolveram maior interesse nos assuntos tecnológicos; alguns se transformariam em inventores e industriais de máquinas. Não são raros os casos em que o machinista ou o lavrador patenteou invenções e aperfeiçoamentos em máquinas de beneficiar café, aproveitando-se da demanda das fazendas e usinas e, inclusive, das garantias da Lei de Patentes de 1830.

Dessa maneira, os processos de concessão de privilégios industriais para a produção de invenções relativas ao trato do café surgem como um indício do esforço brasileiro para a atualização tecnológica do país, seguindo a tendência mundial das sociedades capitalistas no século XIX (RIBEIRO, 1995). O período coincide com aquele em que, ao que parece, ocorreu um surto de invenções e aperfeiçoamentos, levados a termo por inventores nacionais ou estrangeiros residentes, visando a capacitar a produção do principal produto de exportação do Brasil dentro de três circunstâncias iminentes: o fim da escravidão e a expansão do consumo mundial do café; a concorrência de outros países produtores; e a existência de uma legislação e de uma estrutura burocrática favoráveis à inovação tecnológica do meio agrícola. 
[...] privilégio ao que descobrir, inventar ou melhorar uma industria útil e um prêmio ao que introduzir uma indústria estrangeira, e regular sua concessão.

Art. 1. - A lei assegura ao descobridor, ou inventor de uma indústria útil a propriedade e o uso exclusivo da sua descoberta, ou invenção.

Art. 2. - $\bigcirc$ que melhorar uma descoberta, ou invenção, tem no melhoramento o direito de descobridor, ou inventor.

Art. 3. - Ao introductor de uma indústria estrangeira se dará um prêmio proporcionado à utilidade, e dificuldade da introducção ${ }^{13}$.

A lei de 1830 também instituía uma diferença entre o inventor lou machinista) - ou melhorador da máquina - e aquele que introduzia no país uma máquina já desenvolvida no exterior. Ao primeiro, concedia o uso exclusivo do invento; e, ao segundo, gratificava com um prêmio. Esta distinção era necessária, pois, mesmo havendo incremento da indústria de máquinas agrícolas nacionais, existia a necessidade de conter a entrada indiscriminada de inovações produzidas no exterior, nos moldes da chamada Revolução Industrial. Vale lembrar que o período de 1800 a 1850 foi de proliferação do uso de máquinas a vapor nas indústrias inglesas (KATINSKY, 1976).

Para Fernandes, a introdução de máquinas e de técnicas alterava todo o ambiente social e as formas de produção e expansão da lavoura, pois

[a] transplantação [de máquinas] exige algo que transcende ao nível da inteligência do homem: exige mudanças da natureza humana e elas só se produzem com certa lentidão, por serem condicionadas pela organização do ambiente social e pelo emprego que nele se faz das técnicas de socialização ou de educação do homem (FERNANDES, 1960, p. 68).

A lei de 1830 preparava o terreno para a absorção das novas técnicas e equipamentos, e das transformações decorrentes de sua introdução no país. Seu Artigo $4^{\circ}$ destacava a gratuidade da concessão da patente: o inventor ou introdutor pagava apenas as custas do processamento administrativo. Para tanto, era garantido, que

O direito de descobridor, ou inventor, será firmado por uma patente, concedida gratuitamente, pagando só o sello, e o feitio; e para conseguil-a:

1 - Mostrará por escripto que a indústria a que se refere é da sua própria invenção, ou descoberta. $[\ldots]^{14}$.

A lei institucionalizava, ainda, uma política de arquivamento da documentação técnica das invenções, que responsabilizava o Ministério dos Negócios do Império, delegando ao Archivo Publico (atual Arquivo Nacional) o depósito e a guarda do "memorial" dos inventos. Esta tramitação dos requerimentos, exames e depósito dos documentos vigorou até 1860, quando a responsabilidade pelas patentes foi transferida para o Ministério da Agricultura, 
15. ARQUIVO NACIONAL. Inventário Analítico ao Acervo de Privilé gios Industriais. Rio de Janeiro, 1993.

16. COLLECÇÃO..., 1876

17. Idem.

18. Idem.

19. Essa distribuição regional dos estabelecimentos industriais de má quinas de beneficiamento pode ser constatada pelo seguinte anúncio: "JoãoAnastácio Caminha, machinista conhecido e práctico ha vinte annos nas provincias do Rio de Janeiro e Minas, tem a honra de participar aos Srs. fazendeiros que se acha estabelecido com fabrica de machinas de preparar café na cidade de Leopoldina, onde recebe suas encommendas, e se encarrega de fazê-las seguir seu destino.A grande vantagem que têm as machinas é descascar o café sem fazer poeira, e deixalo limpo, sendo preciso apenas ir ao pilão para brunir; a machina tem ventilador e peneira: póde preparar 400 arrobas em 12 horas; isto é, conforme a collocação das ditas machinas, e também se encarrega de dar direcção para o assentamento das mesmas, mediante qualquer quantia, conforme fôr a distância.

As machinas são em tudo iguais às de Ferreira de Assis.

Preço das machinas

n. $1 \ldots \ldots \ldots 000$

Preço das machinas

n. $2 \ldots . .300 \$ 000$

Preço das machinas

n. 1 com

ventilador . . . 850\$000

Preco das machinas

n. 2 com

ventilador . . . .800\$000

[...] Os fazendeiros que quizerem vê-las podem dirigir-se à mesma cidade, na dita fábrica." (Jornal do Commercio, Rio
Commercio e Obras Publicas, permanecendo o Archivo Publico como depositário da documentação comprobatória, caso houvesse ${ }^{15}$.

2 - Depositará no Archivo Publico uma exacta e fiel exposição dos meios e processos, de que se serviu, com planos, desenhos ou modelos, que os esclareça, e sem elles, se não puder illustrar exactamente a matéria ${ }^{16}$

Ao dispensar a apresentação de "planos, desenhos ou modelos", a lei era complacente com aqueles que não eram capazes de desenhar tecnicamente seus inventos e aceitava uma descrição escrita. Cabe ressaltar que tal capacidade de representação técnica era pouco comum, mesmo nos países mais industrializados (LE BOT, 1979).

O Artigo 5o da lei de 1830 também trazia novidades quanto ao prazo do exclusivo da patente: "As patentes se concederão segundo a qualidade da descoberta ou invenção, por espaço de cinco até vinte annos; maior prazo só poderá ser concedido por lei"17.

Contrariamente à concessão do prazo do privilégio, o Artigo $6^{\circ}$ facultava ao governo a compra dos direitos do invento para torná-lo público de imediato. Neste caso, "se o Governo comprar o segredo da invenção, ou descoberta, fal-o-ha publicar; no caso porém, de ter unicamente concedido patente, o segredo se conservará occulto até que expire o prazo da patente. Findo este, é obrigado o inventor ou descobridor a patentear o segredo" 18 .

Desta maneira, em princípio circunscrita ao local de fabricação, as máquinas foram sendo incorporadas cada vez mais ao cenário das fazendas, à medida que as petições de privilégios eram julgadas pela Secção de Machinas e Apparelhos da Sociedade Auxiliadora da Indústria Nacional (SAIN) e divulgadas em folhetins de circulação nacional ${ }^{19}$. Não por acaso, muitos dos próprios inventores de máquinas de beneficiar café - engenheiros, fazendeiros ou machinistas - participavam da composição daquela seção da SAIN e escreviam artigos de divulgação de novos processos e inovações n' $O$ Auxiliador da Indústria Nacional, que eram reproduzidos em jornais das regiões produtoras. Na gestão de 1870-1871 da SAIN, cuja presidência foi exercida pelo conselheiro de Estado e senador José Maria da Silva Paranhos, o visconde do Rio Branco, a Secção de Machinas e Apparelhos tinha como membro o inventor e presidente da Lidgerwood Manufactoring Co. Ltd., Guilherme Van Vleck Lidgerwood (SILVA, 1977).

Já no período em que ocorreu o maior número de requerimentos de privilégio industrial (1870-1889), a presidência da Seção de Macchinas e Apparelhos da SAIN foi exercida por André Pinto Rebouças, principal responsável pelos pareceres encaminhados ao Governo Imperial a respeito dos inventos. Graças ao seu pensamento original sobre o desenvolvimento da economia e sobre a questão agrária e racial do Brasil, Rebouças desempenhou papel fundamental na concretização dos projetos das máquinas. Intelectual refinado, conhecedor das economias européias e norte-americana, este engenheiro negro 
aprofundou o incentivo que a SAIN vinha dando ao desenvolvimento de tecnologia de beneficiamento de café.

Rebouças tinha em mente um projeto modernizador diferenciado para o Império. Baseado na racionalização da produção agrícola, o desenvolvimento no campo passaria pela especialização das regiões e das fazendas em unidades produtoras, encarregadas da produção agrícola, e unidades beneficiadoras, as fazendas que sediariam os engenhos centrais, organizadas em pequenas propriedades e com mão-de-obra nacional livre, pressupondo a extinção radical da escravidão. Em seus pareceres, Rebouças visava à proteção necessária aos inventores para que suas oficinas se desenvolvessem, atrelando seu sucesso ao que supunha ser o interesse do país (REBOUÇAS, 1883).

Isto ocorria porque, desde a década de 1860, havia um consenso entre o governo, a SAIN e os produtores e exportadores com respeito à seguinte questão: a variedade dos tipos de cafés produzidos no Brasil, aliada às doenças das lavouras e outros problemas decorrentes da derrubada e queimada das florestas, forçava o surgimento de inovações de âmbito local ou regional, ampliando a gama de aperfeiçoamentos feitos em invenções originais.

E esta demanda por máquinas modernas também atraía o interesse de fabricantes estrangeiros. A Lidgerwood Manufactoring Company Ltd. tradicional fabricante de máquinas agrícolas dos Estados Unidos da América, que também mantinha fábricas na Escócia - interessou-se pelo mercado consumidor brasileiro. Em 1861 , este fabricante/inventor instalou-se, a princípio, no Rio de Janeiro. Posteriormente, abriu lojas e depósitos de seus produtos em São Paulo, Campinas e Taubaté, de onde funcionava como casa importadora e representante exclusivo das máquinas de costura Singer ${ }^{20}$.

A montagem de uma estrutura de fabricação, importação e distribuição de máquinas agrícolas, caldeiras e turbinas para a geração de energia motriz, e de uma imensa gama de produtos industriais de utilidade cotidiana no meio rural, conferia à marca Lidgerwood uma referência de qualidade entre as máquinas modernas, tornando-as as mais procuradas pelos fazendeiros. Dependendo do caso, porém, também essas máquinas eram montadas junto a equipamentos rudimentares e, muitas vezes, eram acionadas pelo trabalhador/escravo, enriquecendo ainda mais o mosaico de experiências sociais, culturais e tecnológicas experimentado pela sociedade cafeeira do último quartel do século XIX. Bem o demonstra um anúncio do início da década de 1880, em que uma fazenda em local não identificado estava à venda com "[...] 2 rodas, uma de madeira, outra de ferro de 9 metros de diâmetro, machinismos Lidgerwood para café, despolpador, tanques para lavar café, terreiro de pedra e cimento [...] [e] vinte e tantos escravos" ${ }^{\prime 21}$ (grifo do autor).

Entretanto, a invenção e o aperfeiçoamento de máquinas de beneficiar café não se restringiram aos inventores de há muito estabelecidos. A união de fatores como a divulgação de inovações pela imprensa, a demanda da economia cafeeira por alternativas que resolvessem o problema da quantidade e da qualidade do benefíciamento do café, tornando-o independente das condições de Janeiro, p. 5, 4 dez. 1873).

Os processos referentes aos patenteamentos dessas máquinas não foram localizados, permanecendo dúvidas quanto à originalidade dos inventos.

20. As assertivas sobre a Lidgerwood Man. Co.Ltd. estão presentes na maioria de seus anúncios na imprensa, principalmente: Almanak Laemmert 1873, p. 669; Jornal do Commercio, Rio de Janeiro, p. 5, 13 jan. 1880; Correio Paulistano, São Paulo, p. 7, 14 jul. 1904.

21. Jornal do Commercio, Rio de Janeiro, p. 5, 9 maio 1882. 
22. Decreto $n^{\circ} 1337$, de 17 jun. 1857, publicado n'O AUXILIADOR... 1870. p. 50-51. O processo de privilégio industrial (PI) deste invento não foi localizado.

23. O AUXILIADOR..., 1870. p. 50-51

24. O AUXILIADOR... 1873. p. 138. O processo de PI não foi localizado.

25. Idem. p. 499. O pro cesso de PI não foi localizado.

26. O AUXILIADOR... 1874.p. 11. do clima, a economia de mão-de-obra, e a vigência de uma legislação favorável ao inventor nacional ou residente fez surgir um grupo fabricante dessas máquinas no Brasil.

Não surpreende, portanto, que José Frederico Richsen, um dos primeiros inventores brasileiros de máquinas de beneficiar café, tenha se estabelecido graças às decisões da Seção de Machinas e Apparelhos da SAIN. Em 1857, ele conseguiu do Governo Imperial privilégio exclusivo de 10 anos para "construir e vender" ventiladores de café de sua invenção 22 , tendo sido bem sucedido com os aparelhos que exibiu nas Exposições Nacionais de 1861 e 1866, e na Exposição Universal de Paris. Em 1869, Richsen requereu um novo privilégio por 10 anos, para os melhoramentos feitos na invenção original. Despachando sobre esse requerimento, a Secção de Machinas e Apparelhos afirmou que:

[...] $\bigcirc$ privilegiado estabeleceu à ladeira do Barroso n. 5 e $5 \mathrm{~A}$ uma fábrica de ventiladores de café e (cousa rara entre nós) utilisou-se vantajosamente para si e para o paíz, da patente que the foi concedida. [...]

A Secção de Machinas e Apparelhos [...] deverá conceder a requerida renovação do privilégio por mais dez anos não só como premio aos esforços feitos, e aos resultados obtidos pelo inventor, mas também como um efficaz incentivo a novos e mais importantes commettimentos $^{23}$.

mesmo ocorreu com a petição de Américo Salvatori para, por 20 anos, "fabricar e vender a machina de descascar e brunir o café da qual se allegga inventor". Neste caso, a Secção apreciou a invenção criticando o fato de que nela

Surgem [...] os mesmos inconvenientes, que tem sido notados em todas em que se empregão dentes de ferro; taes como o de quebrar ou arranhar o café; o de quebrarem-se os dentes, estorvando ou impedindo o serviço e finalmente o de exigir uma graduação prévia do apparelho, de sorte a deixar passar café miúdo, médio, ou graudo por cada vez.

É portanto inferior a algumas outras machinas já conhecidas.

Entretanto, como convem animar a industria que se refere à preparação do café, por ser este genero a principal fonte da riqueza nacional, e como possa a pratica e o estudo apurado desta machina dar lugar a novos melhoramentos [...] conceda ao requerente um privilegio de dez annos ${ }^{24}$.

A atitude flexível da Secção de Machinas e Apparelhos da SAIN fez com que mais inventores se lançassem àquele ofício empresarial, atraindo também a atenção de alguns grandes fazendeiros que desenvolviam por si soluções para os problemas vividos em seus negócios. Assim fez J. L. de Souza Breves \& Cia., em 1873, quando requereu o privilégio "para um machinismo destinado à conservação do café nos armazens de depósito" 25 . Como não havia um desenho do invento, bastou sua descrição para que a Secção de Machinas e Apparelhos (SMA) o julgasse "[...] um systema simples e racional de conservar o café ao abrigo das intempéries. [...] As disposições são tão elementares que dispensão mais este esclarecimento" 26 . 
Também em São Paulo, o desenvolvimento de máquinas de beneficiamento promovido pelos membros da família de Antonio Carlos de Arruda Botelho, conde do Pinhal, pioneiro de São Carlos do Pinhal latual São Carlos), não deixa dúvidas sobre a importância e o crescente interesse dos fazendeiros no desenvolvimento das máquinas de beneficiar, à medida que a fronteira cafeeira se deslocava para o interior. Somente entre 1889 e 1904, os Arruda Botelho patentearam 20 inventos e aperfeiçoamentos relacionados ao benefício do café27. $\bigcirc$ mesmo ocorreu em Piracicaba com Francisco José da Conceição, o barão de Serra Negra, primeiro a utilizar "apparelhos aperfeiçoados para beneficiar café" no município (VASCONCELOS, 1918, p. 475-476).

Quanto à viabilidade da política de patentes, promovida pela Secção de Machinas e Apparelhos da SAIN com base na Lei de Patentes de 1830, os resultados práticos não tardaram a surgir, justificando os privilégios concedidos. No caso de João Frederico Richsen, já citado, sua indústria fabricava inclusive as malhas das peneiras dos ventiladores. Nessas oficinas - como a de J. F. Tinnuermann, na rua da Ajuda, n. 15, no Rio de Janeiro -, eram produzidos, ao mesmo tempo, peneiras e "...trançado para clarabóias e gaiolas [...], ratoeiras de molas infalíveis, [...] viveiros com ninhos, [...] grelhas para torrar pão, etc. "28.

Em julho de 1875, José Ribeiro da Silva e João Antonio da Silva Peres Júnior, de Cantagalo, Rio de Janeiro, requereram privilégio por dez anos "[...] para usar, fabricar e vender neste Império um apparelho apropriado para descascar e preparar café", chamado Descascador Ribeiro ou Concassor Ribeiro ${ }^{29}$. Em sua petição, os autores demonstraram conhecer o que havia de mais avançado no exterior, não se intimidando em afirmar ser sua máquina superior até mesmo ao Descascador Lidgerwood, uma das mais conceituadas no Brasil. Por conta disto, a Secção de Machinas e Apparelhos receou posicionarse definitivamente, preferindo despachar que

[...] a Secção não póde dar opinião em tão grave assumpto à vista só do desenho do novo descascador; teria muita satisfação em assistir a experiências comparativas.

No entanto, $[\ldots]$ receia que não seja bem sucedida a supressão completa de elementos elásticos no seu descascador ${ }^{30}$.

Não ficava claro como essa máquina inovava em relação às suas predecessoras, mas pode-se dizer que ela abriu caminho para inúmeras outras invenções, na medida em que o Descascador Ribeiro tinha "[...] um elemento mecânico realmente novo e engenhoso $[. . .]^{\prime \prime 31}$, cujo aperfeiçoamento os inventores não deixaram de perseguir. Tanto é que, já no ano seguinte (1876), o Concassor Ribeiro era publicamente apresentado em funcionamento aos fazendeiros da região de Mendes, no Rio de Janeiro, após ter sido premiado na Exposição Nacional de 1875. O machinista chamou os fazendeiros da região para "[... verem praticamente o trabalho admirável de um apparelho tão simples quanto comodo e relativamente barato, e que, sem duvida alguma, vem substituir literalmente quantos engenhos e machinismos se tem empregado até hoje no preparo do café" 32 .
27.A historiografia a respeito dos pioneiros dos municípios cafeicultores do Sudeste brasileiro é insuficiente para a identificação dos autores de invenções entre a nobiliarquia brasileira. O exemplo do município de São Carlos demonstra a oportunidade de pesquisas como a de TRUZZI, Oswaldo. Café e Indústria.São Carlos: 1850-1950. São Carlos: Universidade Federal de São Carlos, 1986. Nesta obra identifiquei na família Arruda Botelho os requerentes dos seguin tes privilégios industriais: Antonio Carlos de Arruda Botelho/PI-6579; Leonardo Botelho/PI-1118, PI1119, PI-1235, PI-1368 e PI-1470; Álvaro Carlos de Arruda Botelho/PI-1395, PI-7535 e PI-8636; Álvaro Botelho, Gautier \& Cia/ PI-2112, PI-2129, PI-2130, PI-6480, PI-6575 e PI7474;Auler, Teixeira e Botelho/ PI-0927, PI-0989, PI-1193 e PI-1201; Elias de Camargo Penteado/PI3806. É possível que outros membros desta família tenham requerido privilégios.

28. Jornal do Commercio, Rio de Janeiro, p. 6 , 27 set. 1874 .

29. Decreto $\mathrm{n}^{\circ} 6020$, de 30 de outubro de 1875 . COLLECÇÃO..., 1876. O processo de PI não foi localizado.

30. O AUXILIADOR... 1875.p.315 e p. 341-342 O processo de PI não foi localizado.

31. Idem. p. 341-342.

32. Jornal do Commercio, Rio de Janeiro, p. 5 , 17-18 abr. 1876. 
33. ARQUIVO NACIONAL. Inventário.... PI07001 .

34. Não foram localizados documentos para verificação da origem desta máquina.

35. ARQUIVO NACIONAL. Inventário.... PI06782

36. O AUXILIADOR... 1879. p. 33-35.

37. Idem. Ibdem.
Em 1878, José Ribeiro da Silva requereu novo privilégio ao Governo Imperial, dessa vez para os melhoramentos feitos no concassor, que chamou de "concassor aperfeiçoado" e ainda "aparelho de descascar café"33 (Figuras 1-3). Neste mesmo ano, voltou ao Governo para patentear outra máquina, o Descascador Congresso. Esse aparelho significava um avanço considerável na adaptação de máquinas agrícolas à indústria cafeeira, pois situava-se entre os moinhos de pedra, usados secularmente, e os descascadores por superfícies reguladas, principalmente o Descascador $\mathrm{Assis}^{34}$. Enquanto este último descascador substituiu os discos de pedra - que tinham o inconveniente do desgaste muito rápido de seus elementos e pouca flexibilidade - por dois discos de ferro canelado, a invenção de Ribeiro aperfeiçoava ambos, na medida em que "[...] a pedra é substituída por um disco de ferro unido a outro de madeira e descasca comprimindo o café de encontro a uma borracha amarella" ${ }^{\prime \prime 2}$.

Dessa forma, o inventor fluminense introduzia a borracha nas máquinas de beneficiamento de café, o que foi logo seguido por diversos autores, pois, pelo sistema de superfícies reguladas, funcionavam também as máquinas construídas com o princípio das mós centrífugas: o Descascador Progresso Mineiro, as Máquinas Albion Coffee Huller, o Descascador de Lidgerwood, os moinhos excêntricos americanos, a Máquina Brazileira, a Turbina Tange-teclas, os cilindros horizontais de capa concêntrica e os descascadores verticais, usados principalmente em Santa Maria Madalena, Cantagalo, São Fidélis, Valença e Vassouras ${ }^{36}$.

Nas inovações anteriores feitas pela indústria inglesa de máquinas, os discos de pedra haviam sido mantidos. Entretanto, ao disco inferior, foi dado movimento contrário ao do superior. Produzida com o intuito de pulverizar grãos, como o trigo e o arroz, essa inovação não se adequava ao descascamento do café, pois quebrava o grão ou não descascava os de tamanho irregular, além de os discos se desgastarem e empastarem com as cascas melosas do café. Os discos de ferro do Descascador Assis resolveram esse último problema, mas continuaram quebrando os grãos maiores que entravam no espaço interno, ou não descascavam os menores. Conforme esclareceu Ribeiro:

Em vista da pequena revista que viemos a fazer, não parece razoável que ao Descascador Assis se aplicasse a borracha? Foi o que realizamos na nossa machina Congresso. Procuramos melhorar a construcção do Descascador Assis e fizemos uma machina pronta para funccionar, simplificando-a o mais que pudemos, afim de seu custo estar ao alcance de todas as fortunas. Entre as modificações que fizemos, há uma que garante maior duração da borracha, e vem a ser a entrada do café pelo centro da mó fixa, que é de borracha. [...]. Essa machina, conquanto descasque o café de uma maneira completa e sem quebrar, tem ainda defeitos sensíveis, mas, remediáveis. O café, no seu estado mais natural, ou em côco, tem a sua casca exterior de natureza quebradiça em uns, macio e melosa em outros, mas sempre rija e dificil de destacar-se. É esta casca que estraga as machinas, e uma borracha do Congresso não prepara mais de quatro mil arrobas de café. No entanto, a borracha, pela sua natureza, é mais própria para terminar o descascamento do que para começá-lo, e, neste caso, sua duração seria muitíssimo maior ${ }^{37}$. 


\section{$x-2,3,2,2=3$ CONCASSOR DE CAFE'}

\section{NOVA MACHNA DE PREPARAR CAFE'}

Privilegiada por decreto n. 0020
desc de Outubro de 1875

E APIROVADA IPLA

Sociedade Auxiliadora da Industria Nacional

Vinceseic e examinalse em casa dos proprietarios

RXBRX@ \& C.

59 Praça do General Pzorio 59

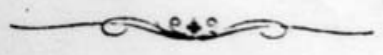

RIO DE JANEIRO

Typ. Moreira, Maximino \& C.-Rua da Quitanda N,11

1875

Figura 1 - Capa de panfleto de divulgação do Concassor de café de José Ribeiro da Silva, 1875. Acervo do Arquivo Nacional, Rio de Janeiro. 


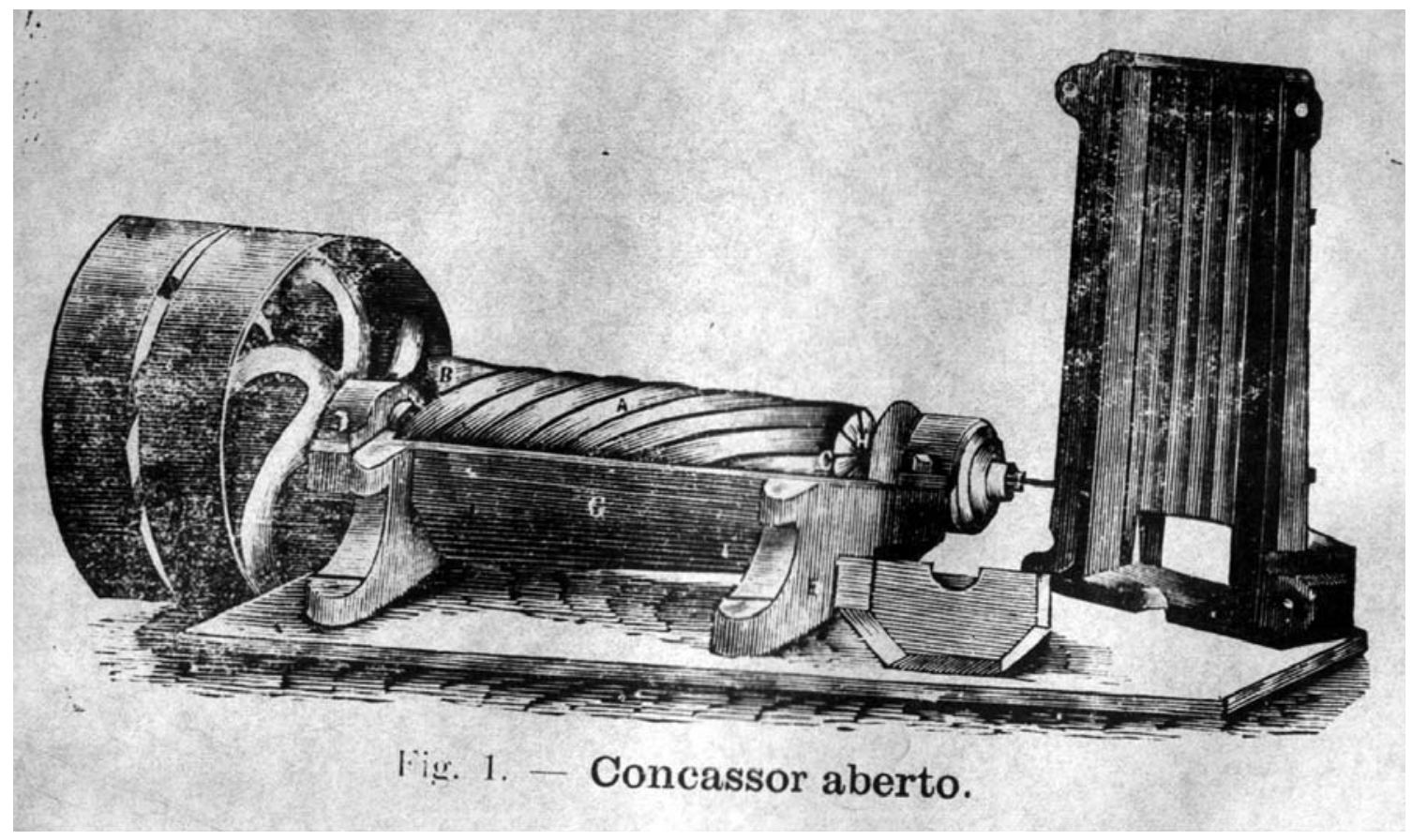

Figura 2 - llustração do Concassor de José Ribeiro da Silva com tampa aberta, em página de panfleto de divulgação, 1875. Acervo do Arquivo Nacional, Rio de Janeiro.

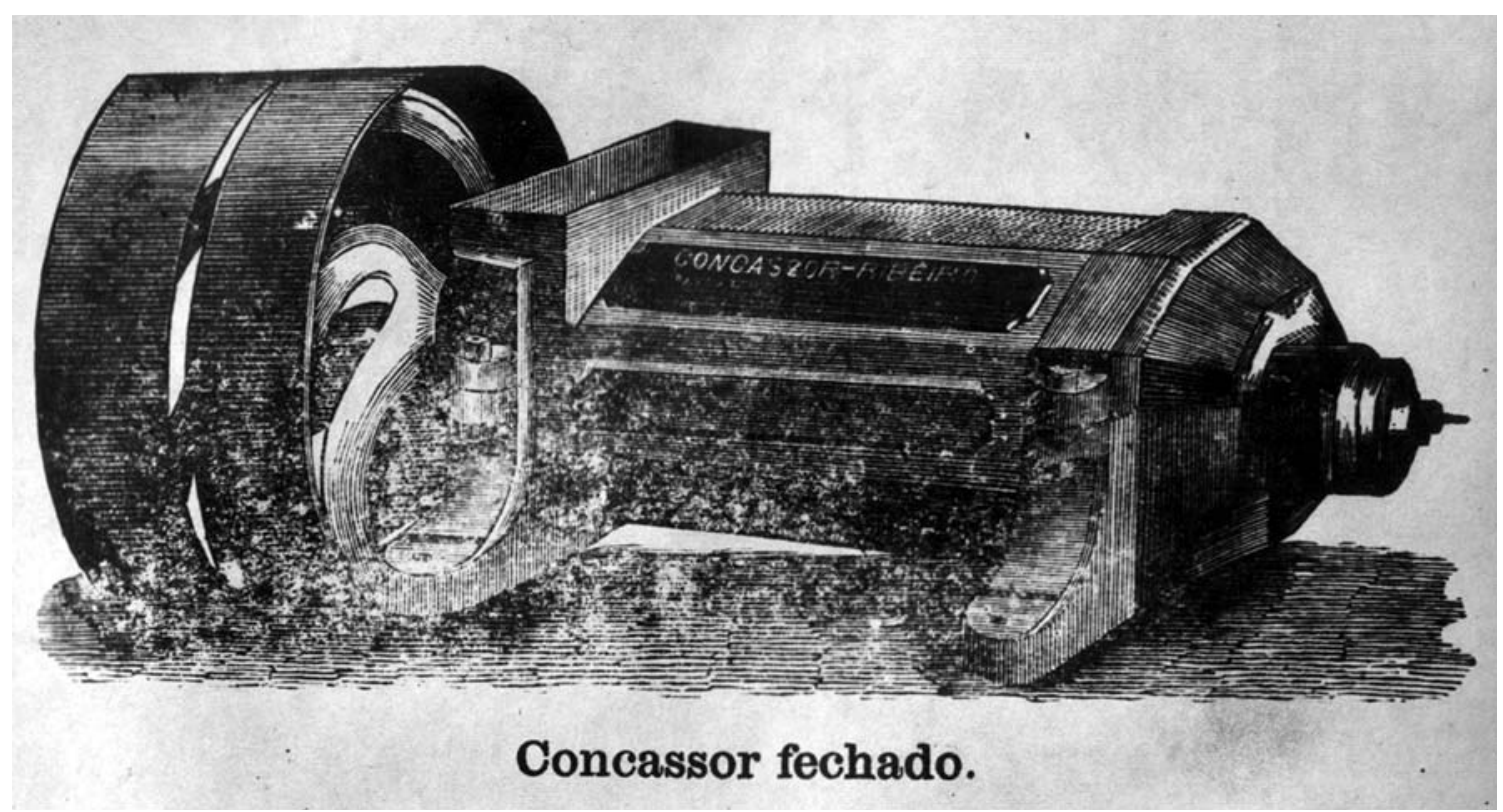

Figura 3 - llustração do Concassor de José Ribeiro da Silva com tampa fechada, em página de panfleto de divulgação, 1875. Acervo do Arquivo Nacional, Rio de Janeiro. 
Uma vez que o próprio autor alterava a disposição de alguns elementos nas máquinas existentes e reconhecia as deficiências de seu aparelho, logo Ribeiro supria o mercado do Rio de Janeiro tanto com borrachas como com as demais peças de reposição do Concassor Ribeiro, oferecendo-as "a preços razoáveis" através da loja dos constructores machinistas Sérgio da Cunha \& Baltar ${ }^{38}$.

A despeito das deficiências que reconhecia existir em seu invento, Ribeiro preparava-se para aperfeiçoá-lo:

Lembramos de construir machinas com descascador mixto de ferro e borracha, cabendo a esta o terminar a operação. Para este fim há dois meios entre outros que nos parecem proficuos: construir uma mó de ferro canelado com um raio ou menos de metade do tamanho total; uma arruela de borracha completará a mó; em frente uma outra mó toda de ferro canelado descascará o café, que entra pelo centro, e terminará o descascamento pela borracha que atinge a periferia.

A outra modificação, conquanto mais complicada, tem a vantagem de se poder regular separadamente os dois operadores; um cylindro com o diâmetro de 20 ou 30 centimetros e coberto de placas descascadoras, pelo systema de Lidgerwood, contem em uma extremidade um disco de ferro canelado e pelo systema do Descascador Assis. O cylindro e o disco são presos a um eixo horizontal, que os anima com um movimento de 300 rotações. Sobre o cylindro há uma capa concêntrica de crivo de arame, por onde o pó tem saída, e em frente ao disco de ferro uma arruela de borracha completa o apparelho.

$\bigcirc$ café entra pela extremidade do cylindro, percorre-o, soffrendo o descascamento, e entra nas mós que o completa de encontro à borracha.

Esta disposição tem mais a vantagem de eliminar a poeira do café antes de entrar na borracha.

Vamos experimentar estas modificações e em breve daremos conta de seu resultado ${ }^{39}$.

Não há indicações de que José Ribeiro da Silva tenha voltado a patentear aparelhos para café, embora outros tenham prosseguido com suas experiências. $\bigcirc$ co-autor da sua invenção original, João Antonio da Silva Peres Júnior, continuou trabalhando individualmente em experiências com a secagem mecânica do café.

Devido à irregularidade da produção da lavoura cafeeira, o processo de secagem representava grande entrave na qualidade do produto. Expostos ao sol em demasia, os cafeeiros produziam frutos com maturação desigual; na mesma planta eram retirados frutos maduros (cereja), frutos já secos antes de colhidos (coco) e, ainda, frutos verdes. Além disso, o café era colhido num movimento de mão chamado derriça, que consistia em envolver a base do galho com os dedos e percorrê-lo até a ponta, arrancando assim frutos, cascas, folhas, etc. Apesar de o método da derriça proporcionar maior produtividade por trabalhador, deixava por ser feita a tarefa da separação dos grãos diferentes (em tamanho e maturação) e a da retirada de corpos estranhos: folhas, cascas, pedras, paus, etc. $\bigcirc$ resultado desse trato agrícola recaía na qualidade do café exportado e na sua fama de produto inferior nos mercados externos. Isso explica porque os fazendeiros se interessavam por máquinas que igualassem os grãos durante a secagem e os separassem conforme suas propriedades físicas. 
40. O AUXILIADOR..., 1883.p. 35-39.

41. Idem. Ibidem.

42. Idem. Ibidem.

43. ARQUIVO NACIONAL. PI-08126.
A secagem mais comum do café era a de terreiro. As partidas vindas da lavoura eram despejadas em terreiros cercados e calçados de pedra e cal nas fazendas mais equipadas; depois os escravos e colonos revolviam todo o café com rodos de madeira várias vezes por dia durante um período que variava com as condições climáticas e pluviométricas. Dessa forma, a secagem, fase inicial do benefício do café, fugia ao controle do fazendeiro.

Analisando as dificuldades técnicas e o alto custo da secagem para o produtor, Louis Couty, lente de biologia industrial da Escola Polytechnica e sócio da SAIN, assim se referiv:

Em uma fazenda de 30.000 arrobas, a operação do secamento dura de cinco a seis meses, e, por todo esse tempo, dez pessoas pelo menos, ocupam-se, da manhã à noite, em riscar - revolver com rodo - o café no terreiro. Além disto, é ele espalhado, ao esquentar o sol, pela gente disponível nas proximidades do terreiro, e à noitinha os escravos, ao voltarem da roça, vem reunílo em montes. Não consideremos o gasto de mão-de-obra com a primeira operação, e só atendamos à segunda. Calculando a sua duração em uma hora - de ordinário e de mais - e sendo de 150 o número de trabalhadores lo que dá para uma produção de 30.000 arrobas, 200 arrobas por escravo, resultado só obtido com gente muito boa), aí estão 150 horas gastas ou o serviço de 15 pessoas. Assim o terreiro absorve diariamente $\mathrm{o}$ trabalho de 25 pessoas $^{40}$.

\section{E continua:}

[Se] sobrevém uma trovoada durante o dia, imediatamente todos os braços, até pedreiros, carpinteiros, pagens, mucamas, etc., abandonam as ocupações, e, a trote largo, como dizem, tratam de recolher o café às tulhas. Quando o aguaceiro cai ou ameaça cair alta noite, as coisas são ainda piores. Tange o sino de alarma, e os míseros escravos, arrancados violentamente ao sono, vêm, quentes da cama e sem precaução alguma, expor-se a todas as intempéries e esvaziar o terreiro, para talvez tornar a enchê-lo no dia seguinte, passada a tormenta. Quantas moléstias não são devidas a isto? ? $^{41}$.

Para finalizar, afirma:

Sabem os fazendeiros que muitos escravos são vítimas de pneumonias e outras afecções apanhadas nessas ocasiões, daí provindo perda considerável e definitiva de mão-de-obra ${ }^{42}$.

As experiências com secagem mecânica do café multiplicaram-se. As primeiras foram aquelas em que as estufas se assemelhavam a grandes fornalhas, aquecidas por queima de lenha ou outro material orgânico. Depois surgiram experiências mais complexas, que introduziam o ar aquecido sob pressão nas câmaras de secagem, e outras que utilizavam o vapor sob pressão, aquecendo o secador, enquanto a umidade era retirada por outro lado, sob a ação de bombas pneumáticas.

Portanto, parte das patentes requeridas referia-se a secadores de café. Uma delas foi a do ex-parceiro de José Ribeiro da Silva, João Antonio da Silva Peres Júnior, que desenvolveu a Estufa Automática para Seccar Café - A Cantagallense e a patenteou em $1879^{43}$. Segundo ele, tratava-se de uma máquina 
que secava o café "[...] por meio da acção direta de ondas caloríficas irradiadas dentro de um forno, auxiliado pelo ar, altamente aquecido e confinado no mesmo, onde o café demora-se por tempo determinado em um cylindro ôco animado de um movimento de rotação lenta, e d'onde os vapores aquozos são extrahidos $[\ldots]^{\prime \prime 4}$.

Dentre as muitas experiências feitas com secadores, merecem registro as realizadas por Daniel Pedro Ferro Cardoso e John Sherrington, do Rio de Janeiro, com o Seccador Pneumático, patenteado em $1877^{45}$. Segundo eles, sua máquina aperfeiçoava a utilização do ar quente e do vácuo, na medida em que o ar não entrava em contato com o café posto para secar: "[...] nós procuramos retirar o mais completamente que possível o contacto desse ar com o objecto a seccar assim como evaporar por meio do vacuo e do calor todo o liquido contido no paranchima do mesocarpo ou involucro d'elle"46.

Seccador Pneumático tinha um compartimento hermeticamente fechado, onde ficava o café; um sistema de tubos ligados à caldeira, para manter a temperatura interna; uma bomba pneumática, para a produção do vácuo no compartimento de café; e, ainda, um manômetro e um termômetro, para o controle das pressões e temperaturas internas.

No mesmo ano, Ferro Cardoso voltou a patentear. Dessa vez o privilégio foi requerido para uma inovação no invento anterior: "[...] lembrei-me de applicar ao seccador acima mencionado um condensador[...]". A nova máquina foi batizada como Seccador Pneumático a Condensação ${ }^{47}$. Em seu requerimento, porém, o autor fez questão de registrar para si a autoria exclusiva da inovação, apontando para uma disputa que comumente acontecia entre inventores e patenteadores de máquina: "[...] deposito esta descripção no Archivo Público sob minha unica responsabilidade scientifica para me servir de prova contra os desleaes e prevaricadores ou falsários" 48 .

Graças à enorme capacidade para adaptar às máquinas de beneficiar café os recursos tecnológicos disponíveis em outras atividades, Ferro Cardoso adicionou, em 1879, outro melhoramento à sua invenção original, que passou a se chamar Machina Daniel para Seccar Café. Na nova máquina, o autor, atento para a baixa produtividade do aparelho, adaptou-the um sistema de tubos para aquecer mais rapidamente o ar, e gavetas com fundo de telas de arame, onde o café era posto para secar ${ }^{49}$. Ao mesmo tempo, Ferro Cardoso patenteou um aperfeiçoamento à primeira inovação que fizera no seu secador original, introduzindo um condensador no processamento. Nessa nova máquina, em que o "architecto" rebatizou o Secador Pneumático a Condensação com o nome de Seccador Ferro Cardoso50, a inovação consistia na adaptação de um "[... condensador idêntico ao que se emprega nas caldeiras de vácuo para a cristalização do assucar; isto é condensação que é feita por meio da introducção d'água fria que vae condensar os vapores formados no recinto hermeticamente fechado onde se acha depositado o café"

Pelos registros posteriores, o inventor não conseguiu reduzir tanto o tempo de operação do secador. Seu invento continuou a ser vendido para secar em oito horas o café colhido no mesmo dia e em seis horas o café colhido com
44. Idem.

45. ARQUIVO NACIONAL. PI-07028.

46. Idem.

47. ARQUIVO NACIONAL. PI-07040.

48. Idem. Uma pesquisa mais aprofundada acerca das disputas pelos direitos autorais de máquinas de beneficiamento de café poderá servir-se, principalmente, da documentação judiciária do Arquivo Nacional e da do Centro de Memória da Unicamp.

49. ARQUIVO NACIONAL. PI-06657.

50. ARQUIVO NACIO NAL.PI-06683. O inventor Daniel Pedro Ferro Cardoso, ex-membro da Seção de Artes Liberaes da SAIN, foi tratado por "architecto", na SAIN, quando propôs à Sociedade, em 1876, que o Brasil sediasse uma exposição universal no Rio de Janeiro, a ser aberta em abril de 1880 (O AUXILIADOR..., 1876. p. 286 287).

51. ARQUIVO NACIONAL. PI-06683. 
52. O Jornal do Commer cio (p. 5, 21 maio 1882) publicou carta de Frederico Carlos da Cunha e Cia aos fazendeiros, convidando-os para a demonstracão da"Machina de seccar em seis horas, o café cereja", inventada por Dr. Ferro Cardoso, no domingo, 28-05-1882, nas oficinas de fundicão dos Srs. Fin nie Comp.na rua Cons. Zacharias, 4 - Saúde. O anúncio dizia que "a baixa do café nos mercados impõe aos srs. fazendeiros a necessidade de procurar o meio de produzir o café bom e a preco mais modico do que actualmente. Ora, como seja incontes tavelmente, na produção do café, a parte mais dis pendiosa, lenta e trabalhosa o secca-lo; segue-se que o apparecimento de uma machina, que, sendo de custo barato, de modo a achar-se na altura das pequenas fortunas, secasse $o$ café em cereja em muito pouco tempo e sem alterá-lo, seria, para a lavoura, o melhor auxílio que ella poderia obter para uma producção econômica.

Ainda maior seria a vantagem, se essa machina no próprio trabalho de secca do café despolpasse-o todo e mesmo des cascasse-o em grande parte. [...] Cumpre fazer tornar bem saliente que o café secco por machina sahe todo com uma uniformidade, de cor admirável, qualquer que se ja a diferença no estado de maturição de cereja que fôr empregada, isto é, a mistura de cafés verdes, seccos e maduros".

53. Decreto ${ }^{\circ} 6135$, de 4 de março de 1876 (COLLECCÃO..., 1876). O processo de PI não foi localizado.

54. O AUXILIADOR... 1876. p.7.

55.Jornal do Commer cio, Rio de Janeiro, 6 maio 1876. três dias de antecedência. Entretanto, as máquinas - cujos preços variavam entre 4:000\$000 (quatro contos de réis), para secar 50 alqueires em seis horas, e 6:000\$000 (seis contos de réis), para secar 100 alqueires em seis horas ofereciam uma vantagem adicional, que justificava seu custo elevado: quando o café era cereja, ela o despolpava, ou seja, extraía a espessa polpa que envolve o grão; depois, descascava-o em parte, isto é, extraía a membrana que envolve o grão. Quando o café já entrava despolpado, a máquina devolvia-o completamente seco em cinco horas ${ }^{52}$.

Ainda na década de 1870, muitos autores se destacaram na produção de uma linha de descascadores de café. Em 1876, Bernardino Corrêa de Mattos, um dos mais proeminentes, requereu patenteamento para a Machina Brasileira para descascar café ${ }^{3}$. Ao analisar sua petição, a Secção de Machinas e Apparelhos da SAIN deliberou favoravelmente ao privilégio sem exigir comprovação prática.

Oaparelho continha princípios que o aproximavam do Concassor Ribeiro. Entretanto, a Secção de Machinas e Apparelhos recomendou a concessão do privilégio por dez anos por entender que a nova máquina diferenciava-se do Concassor Ribeiro:

1ํ Nas disposições dos cones descascadores, que em uma é inversa da outra.

$2^{\circ}$ Em ser acompanhado o descascador de todos os accessorios necessarios para dar o café logo prompto para ser ensacado 54 .

De fato, a Machina Brazileira para descascar fora projetada com cilindros de chapas de aço temperado, com a finalidade de dar-the uma vida útil de 225 a 300 toneladas (20 mil arrobas). Expostos aos fazendeiros na Estação do Commercio da Estrada de Ferro Pedro II, em maio de 1876, os três modelos - com capacidade para descascar $750 \mathrm{~kg} /$ hora, $450 \mathrm{~kg} /$ hora e 225 $\mathrm{kg} /$ hora (respectivamente 50, 30 e 15 arrobas, na linguagem da época) -, recebiam o café seco de terreiro (ou coco) em sua moega e, em 15 minutos, podiam "lançá-lo no sacco, já brunido e prompto para ser exportado" (Figuras 4-7).

Na opinião dos 20 fazendeiros que utilizaram a máquina, suas vantagens adicionais eram as seguintes: funcionar com motor a água, de potência de três a sete cavalos, segundo o modelo; ocupar apenas "25 palmos quadrados" para sua instalação; ser movida por apenas "1 escravo ou empregado" e, finalmente, apresentar índice de quebra de apenas 1/4 de arroba (cerca de quatro quilos) em cada cem arrobas (cerca de 1500 quilos) de café descascadas ${ }^{55}$

Em 1879, a empresa Corrêa, Mattos \& Cia., de Bernardino Corrêa de Mattos, já mantinha um representante na rua da Saúde, nº 14, na Corte, para distribuir os catálogos de suas máquinas, amplamente utilizadas nas fazendas de Valença, Vassouras e Parayba do Sul, na província do Rio de Janeiro, e em Leopoldina, província de Minas Gerais. Além do descascador, o inventor oferecia máquinas distintas, para ventilar e para brunir o café ch $^{5}$. 


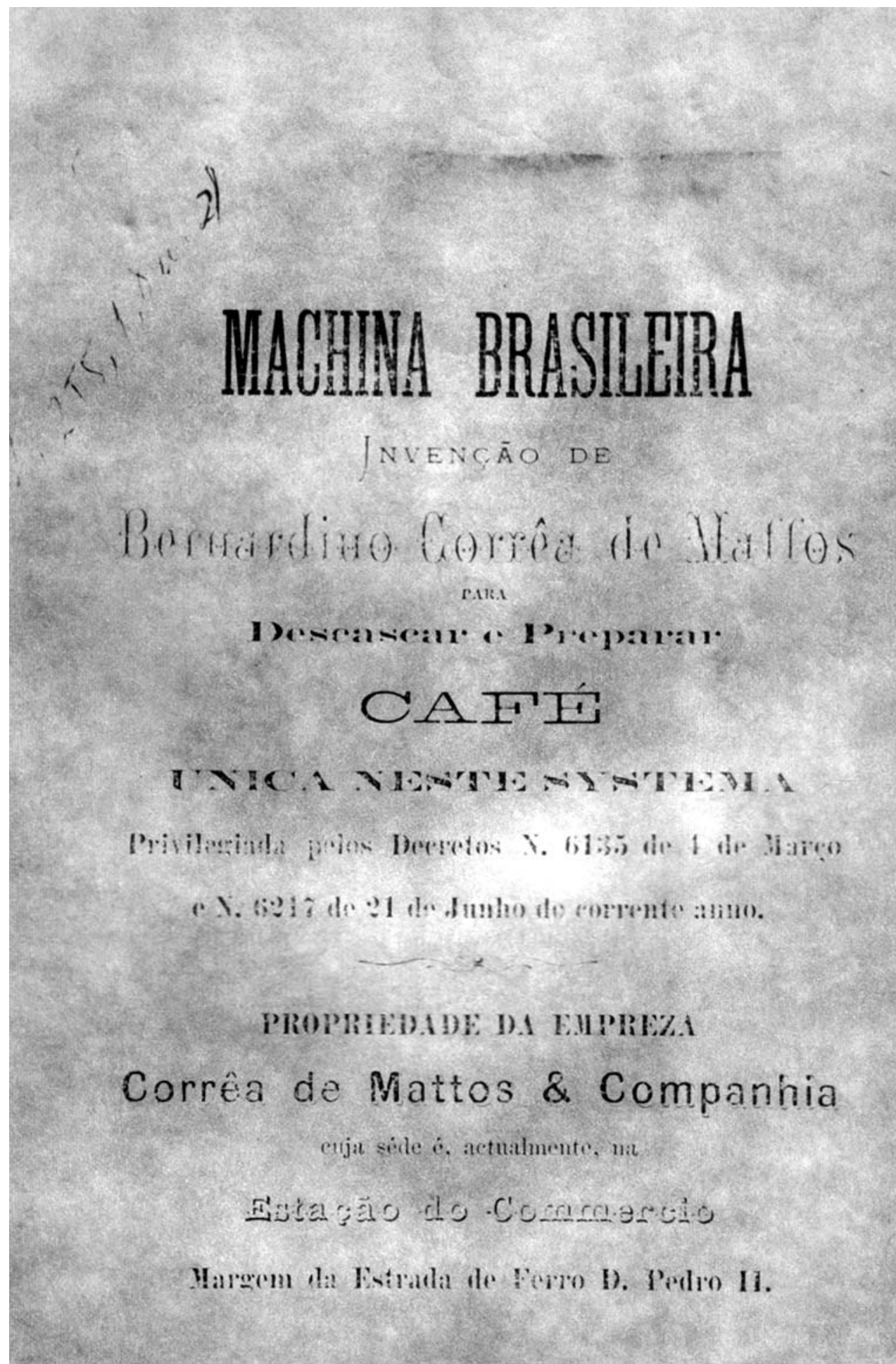

56. Jornal do Commercio, Rio de Janeiro, p. 7,7 fev. 1879. O processo de PI não foi localizado

Figura 4 - Capa de panfleto do fabricante Bernardino Corrêa de Mattos, 1876. Acervo do Arquivo Nacional, Rio de Janeiro. 


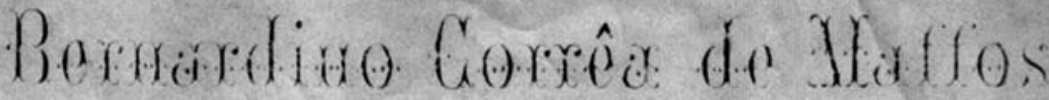 r.M.A.}

Descasear a Preparar.

\section{CAF甶}

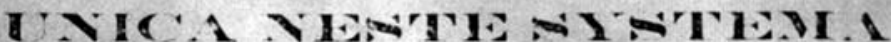

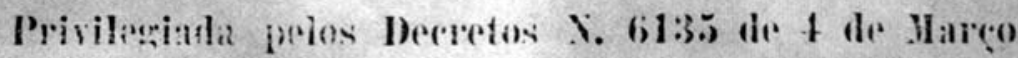

e X. 6:1 2 de 21 de Jumho do corrente :mino.

\section{PROPRIED.IDE D.1 EMPREZ.1}

Corrêa de Mattos \& Companinia cuja séde é, actualmente, na

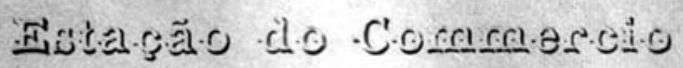

Margem da Estrada de Ferro D. Pedro 11.

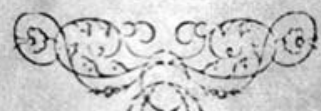

Rxo DE JANXxo

Typ. de Pereira Braga if (.., rua Nova do Ouvidor 11.25

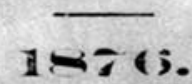

Figura 5 - Página de panfleto do fabricante Bernardino Corrêa de Mattos, 1876. Acervo do Arquivo Nacional, Rio de Janeiro. 


\section{Pređ̣es Fixes}

A machina para descascar, com ventilador annexo-fig. - D. 2:000\$000

Dita com dito e brunidor-figs. - D - F . . . . . 2:500\$000

Um brunidor em separado-fig. - F. . . . . . 7003000

Um ventilador auxiliar - fig. $-\mathrm{E}$. . . . . . . . $500 \$ 000$

A machina completa, conforme a estampa em frente. . . 3:000\$000

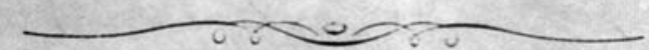

Figura 6 - Página de panfleto do fabricante Bernardino Corrêa de Mattos com tabela de preços da Machina Brasileira completa ou com opcionais, 1876. Acervo do Arquivo Nacional, Rio de Janeiro. 


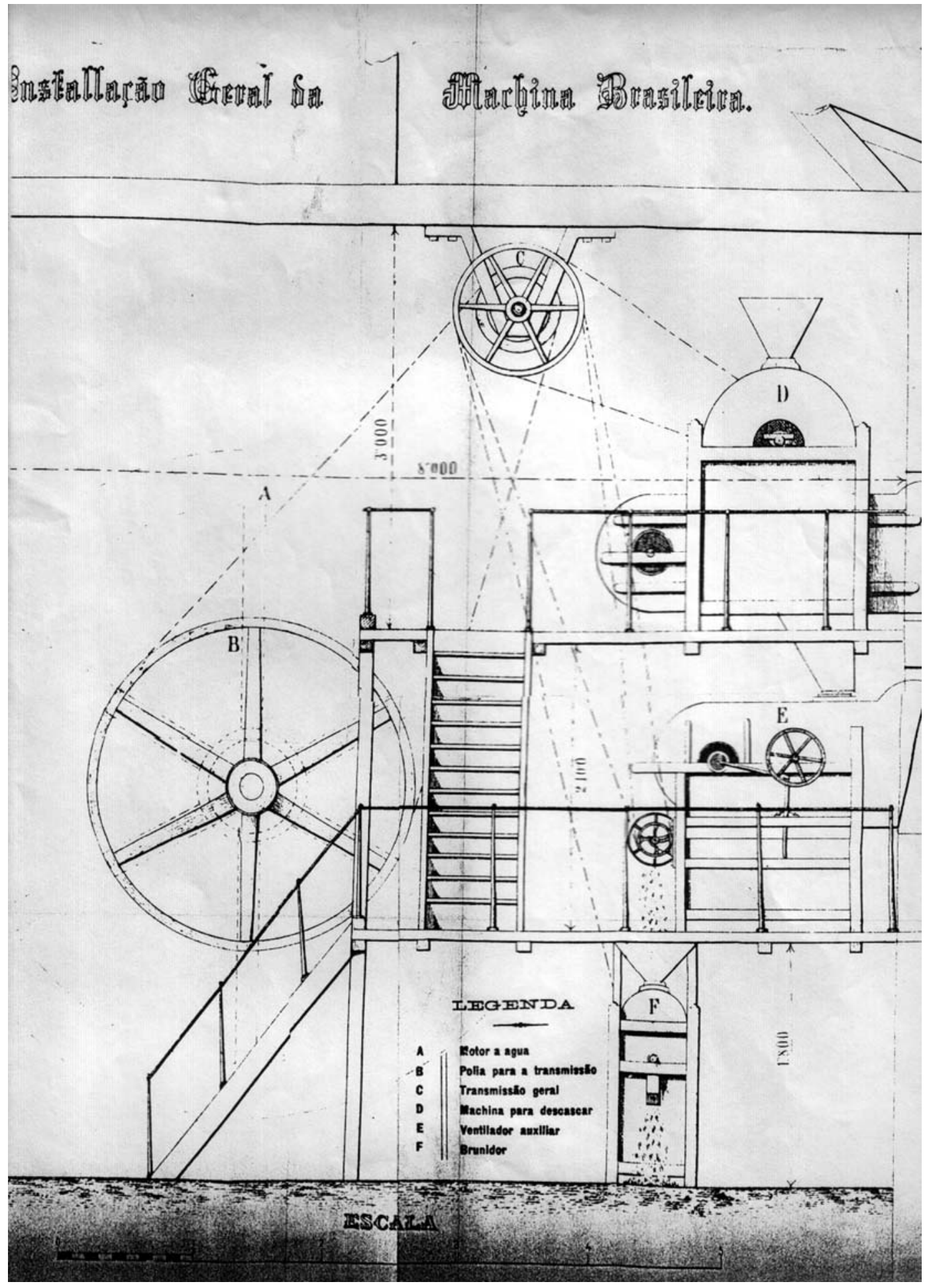

Figura 7 - Aspecto da Installação Geral da Machina Brasileira, 1876. Acervo do Arquivo Nacional, Rio de Janeiro. 
Entre outras invenções desenvolvidas em descascadores, obteve repercussão a Máquina Mineira, patenteada em 1879 por José Jacinto Melo, de Mar de Espanha, Minas Gerais, destinada a "descascar e ventilar o café" 57 . Apesar de seu patenteamento só ter sido requerido naquele ano, essa máquina já tinha sido experimentada por 34 fazendeiros da região, que manifestaram publicamente sua aprovação:

Nós abaixo assinado, fazendeiros residentes neste município, tendo assistido ao primeiro ensaio da machina de soccar, descascar e ventilar café, da invenção do artista mechanico José Jacintho de Mello, e, sendo sem duvida alguma de maxima vantagem para o fim que é destinado, porque vimos em um minuto preparar uma arroba de café; que no correr de doze horas que tem o dia, pode apromptar 120 arrobas, viemos por este meio dar-the uma prova de consideração e apreço por este importante melhoramento agrícola, devido por certo a seus acurados esforços e superior intelligência ${ }^{58}$.

Outra descascadora de relativa importância foi a Turbina Tange-teclas, desenvolvida em Campos (RJ), por Miguel Alamir Baglioni, e patenteada no início de 1880. Segundo o autor, a "machina de preparar e picar o café" 59 fora idealizada para "descascamento por superfícies reguladas" e seu funcionamento baseava-se no atrito provocado por duas superfícies "rugosas e animadas por movimentos contrários", e a distância entre elas era dada pelo tamanho do grã $0^{60}$

Enquanto se desenvolvia a produção de secadores e descascadores, crescia também o interesse dos inventores em patentear ventiladores independentes ou acoplados aos descascadores, para separar os objetos estranhos e as cascas retiradas dos grãos no processo de descascamento. Um aparelho com esse fim foi desenvolvido por Henrique Delfim Duprat, de Cantagalo (RJ), que o patenteou em 1880, sob o nome de "Ventilador a Prumo [...] destinado à separação da casca e diversas qualidades de café depois de descascado"bl. Esse equipamento popularizou-se como Ventilador Duprat (Figura 8). $\bigcirc$ inventor requereu para si o privilégio, por ter introduzido nos ventiladores até então conhecidos a novidade da "[...] pozição vertical do tubo de propulsão do ar e onde opera a ventilação", afirmando ser essa concepção mecânica "[...] toda nova e de invenção particular"b2. Em algumas fazendas, as cascas viravam combustível nas fornalhas das caldeiras ou eram empregadas na adubação dos terrenos, como recomendavam André Rebouças e Nicolau Moreira ${ }^{63}$.

No ano seguinte, Duprat requereu um privilégio industrial para o aperfeiçoamento que realizara naquele ventilador, com a finalidade de abreviar o processo de secagem. Enquanto "[...] no ventilador privilegiado o café [...] tinha de ser submettido a dois processos de ventilação, [...] com o melhoramento feito, póde conseguir-se o mesmo resultado com uma só operação e ainda com a vantagem de separar todo o café preto $[. . .]^{\prime \prime 64}$.

Tudo leva a crer que as máquinas produzidas por Duprat foram um sucesso. Isso porque, no começo do século XX, elas ainda eram oferecidas ao público pelo comércio especializado em equipamentos mecânicos do Rio de Janeiro, juntamente com outros equipamentos congêneres de invenção nacional
57. ARQUIVO NACIONAL. PI-07096.

58.Jornal do Commercio, Rio de Janeiro, p. 4, 5 set. 1878.

59. ARQUIVO NACIONAL. PI-07735.

60. O AUXILIADOR..., 1879.p. 35.

61. ARQUIVO NACIONAL. PI-06687.

62. Idem.

63. Em seus artigos sobre a agricultura brasileira, Rebouças fez observações como esta: "Os resíduos do café e de qualquer outro produto agrícola são excellentes restauradores (estrumes, adubos) dos terrenos, que deram essa colheita. Não queimeis as cascas de café, e quando cometerdes esse erro econômico apanhai, cuidadosamente as cinzas, e utilizaias como estrume mineral nos vossos cafezais [...]" (REBOUÇAS, 1883, p. 140). Do mesmo tema tratava Nicolau Moreira, nos diversos artigos sobre "Economia Rural" que publicou em O Auxiliador da Indústria Nacional na década de 1880.

64. ARQUIVO NACIONAL. PI-07738. 


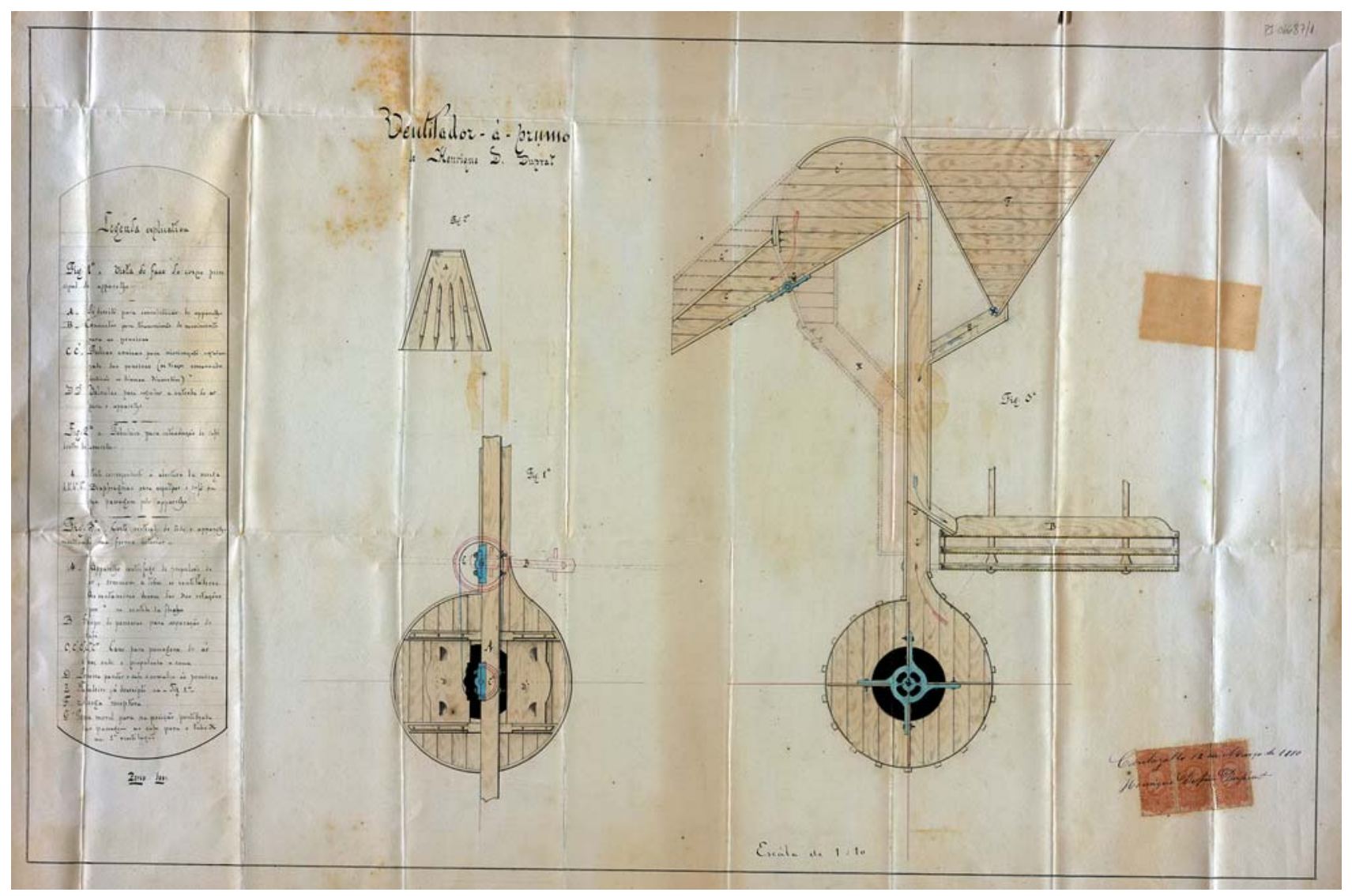

Figura 8 - "Vista de face do corpo principal do apparelho" Ventilador a Prumo, 1880. Acervo do Arquivo Nacional, Rio de Janeiro.

65. Jornal do Commercio, Rio de Janeiro, 5 maio 1902 .

66. Jornal do Commercio, Rio de Janeiro, p. 4,6 jan. 1878. O processo de PI não foi localizado. ou estrangeira. Em 1902, por exemplo, a Casa de Hampshire \& C., da rua Visconde de Inhaúma, n.40, anunciava ter em estoque de "machinas de beneficiar café - Ventiladores Duprat, [...e] Brunidores Bierrembach...", este último fabricado em Campinas ${ }^{65}$.

$\bigcirc$ primeiro registro da invenção de João Miguel Bierrembach, de Campinas, data de 1878. Tratava-se do patenteamento requerido para o Brunidor Paulista, uma máquina, como o nome o diz, capaz de brunir. $\bigcirc$ brunimento é a última operação do benefício, quando o grão do café, livre da película que o envolve, recebe um polimento para melhorar sua aparência e torná-lo mais impermeável à umidade, além de separar os diferentes tamanhos dos grãos de café através do peso. Seu efeito representava uma cotação melhor para o produto e maiores lucros ao fazendeiro.

As máquinas de Bierrembach funcionavam nas fazendas dos barões de Aparecida (Rio Bonito), em Sapucaia (RJ); e nas fazendas do Dr. Antonio José Vieira Machado, de Francisco Machado Marcondes, do Dr. Luiz Augusto Correa de Azevedo, e também em duas fazendas do Comendador Vergueiro, em Ibicaba (SP); e na fazenda do Marquês do Paranább. 
Face ao grande volume do café produzido em cada fazenda, o brunimento, por suas características, era uma operação impossível de ser realizada manualmente. Para melhor adaptar-se ao porte das fazendas, o Brunidor Paulista era produzido em duas versões: o Brunidor 1, de capacidade para 300 arrobas/dia, custando $700 \$ 000$ (setecentos mil réis); e o Brunidor 2, para 150 arrobas/dia, ao preço de 550\$000 (quinhentos e cinqüenta mil réis). Ambos eram montados, pelo fabricante, na fazenda do cliente ao custo adicional de $100 \$ 000$ (cem mil-réis) 67.

No mesmo ano de 1878, João Miguel Bierrembach obteve patente de privilégio também para o Cecador Paulista ${ }^{68}$, um sistema de superfícies planas móveis, dentro de uma câmara de aquecimento (em forma de casario de alvenaria) encarregada de, durante o processo de secagem, receber os grãos de café e repassá-los à superfície plana seguinte. Essa máquina substituía o terreiro de secagem natural. Em seguida, patenteou um melhoramento ao secador original, dispondo os terreiros em série, de forma que "[...] esses terreiros percorrem o seo movimento sem fim", melhorando a distribuição do café no secador através do aperfeiçoamento do sistema de rotação dos terreiros ${ }^{69}$.

Em 1881, Bierrambach voltou a aperfeiçoar seu secador de café, desta vez ampliando sua aplicação também para o descascamento do café já despolpado, "[...] prestando-se também para beneficiar cereais"70. Bierrembach assim enumerou as vantagens de sua nova máquina:

1 Facilitar o lavrador a beneficiar o café em 2 ou 3 dias depois de colher $2^{\circ}$ Não ter mais café preto ou de qualidade inferior, consequencia da fermentação havida nos terreiros.

3 Melhorar a qualidade do café que offerece ao mercado.

4ํㅡㄹ Dispensar os terreiros de seccar tão dispendiosos.

5ํㅡㄹ Desaparecer o contínuo e fastidioso trabalho de mecher e recolher-se o café diariamente pelo espaço de 30 dias como até aqui se tem feito ${ }^{71}$.

As máquinas produzidas pelo "inventor e fabricante" de Campinas atingiram logo boa reputação no circuito de produção do café, passando a manter a firma Monteiro, Hime \& $\mathrm{Co}^{72}$ como representante exclusivo na Corte. Além disso, ele próprio enviava aos jornais amostras dos cafés beneficiados por suas máquinas, uma estratégia eficiente para aumentar a credibilidade de seus produtos. Em vista disto, o Correio Paulistano referia-se a ele como o "acreditado industrial da cidade de Campinas"73, ao divulgar as vantagens de sua nova máquina de secar café em dez horas. $\bigcirc$ jornal destacava a experiência realizada na Fazenda Monjolinhos, do Comendador Souza Barros, quando o secador produziu uma secagem perfeita de um café de qualidade superior, " ...conservando a côr natural"74.

Apesar de não ter enviado repórteres para documentar a experiência, - Correio recebeu aquela inovação com entusiasmo, condicionando sua
67. Idem. Ibidem.

68. ARQUIVO NACIONAL. PI-08799.

69. ARQUIVO NACIONAL. PI-06640.

70. ARQUIVO NACIONAL.PI-8192;PI-6781.Dada a semelhança dos relatórios autorais, é possível tratar-se do mesmo patenteamento.

71. ARQUIVO NACIONAL. PI- 08192.

72. Jornal do Commercio, Rio de Janeiro, p. 6 , 22 abr. 1881.

73. Correio Paulistano, São Paulo, p. 2, 6 abr. 1881.

74. Ibidem 
78. Idem.

79. Idem. receptividade à capacidade do invento de superar os problemas representados pelo terreiro de secagem natural.

Não temos conhecimento circunstancial da machina inventada pelo Sr. Bierrembach, mas se puder ella seccar quantidade de café correspondente à colheita ordinária de nossas fazendas, o seu emprego será de grande utilidade à lavoura do café, acabando ou diminuindo a necessidade do serviço de terreiro, que exige grande número de braços e que occasiona, às vezes grandes prejuizos, pela demanda do seccamento.

Em todo o caso o Sr. Bierrembach merece elogios pelos esforços que está empregando no sentido de facilitar o processo de beneficiamento do café, uma das maiores difficuldades com que luta a nossa lavoura ${ }^{75}$.

João Miguel Bierrembach desenvolveu ainda outro aperfeiçoamento do secador original, dessa vez no sistema de secagem. Esse sistema, funcionando através da passagem de ar quente exaustado por um ventilador, oferecia dificuldades, para o inventor, na montagem e alto custo de operação. Por isso o secador patenteado em fevereiro de 1882 caracterizava-se por ser uma máquina que

Concentra em si todos os predicados das outras nossas machinas [...] somente tornou-se mais resumido, dispensando casa própria, exigindo muito pouco combustível [...], em condicções de ser fabricado na officina todo completo, visto que é construído todo de ferro, dispensando portanto o trabalho de carpinteiros, pedreiros etc. nas fazendas e por esta razão ao alcance da pequena lavoura ${ }^{76}$.

Um outro secador obteve grande repercussão no circuito do benefício do café. Trata-se da Machina de Seccar Café Taunay-Telles, desenvolvida e patenteada em maio de 1880 pelos engenheiros, e membros do Instituto Polytechnico Brasileiro, Luiz Goffredo de Escragnolle Taunay e Augusto Carlos da Silva Telles (Figuras 9-1 1 177.

Essa máquina, ao que parece, tinha como maior mérito um sistema composto por duas câmaras cilíndricas de eixo comum, sendo uma interna à outra:

cylindro exterior é fixo, preso a uma [...] dupla folha [...]; no espaço existente entre ella e a parede do cylindro exterior fes-se circular o vapor de agua ou o ar aquecido. $\bigcirc$ cylindro interno [...] apresenta na superfície interna espécies de alcatruzes - dispostas longitudinalmente $[\ldots]^{78}$.

No relatório autoral que acompanhou a petição do privilégio, os autores já demonstravam a intenção futura de estudar uma variante que substituísse as alcatruzes da máquina por um terceiro cilindro de raio menor, no mesmo eixo: "A superfície d'este terceiro cylindro é crivado de orificiosinhos e sustenta uma helice de espiras muito juntas [...]" $]^{\prime 79}$. Quanto ao funcionamento da máquina, enquanto o vapor de água ou o ar aquecido era introduzido no cilindro maior, fixo, o café a secar era posto no cilindro interno, móvel: 


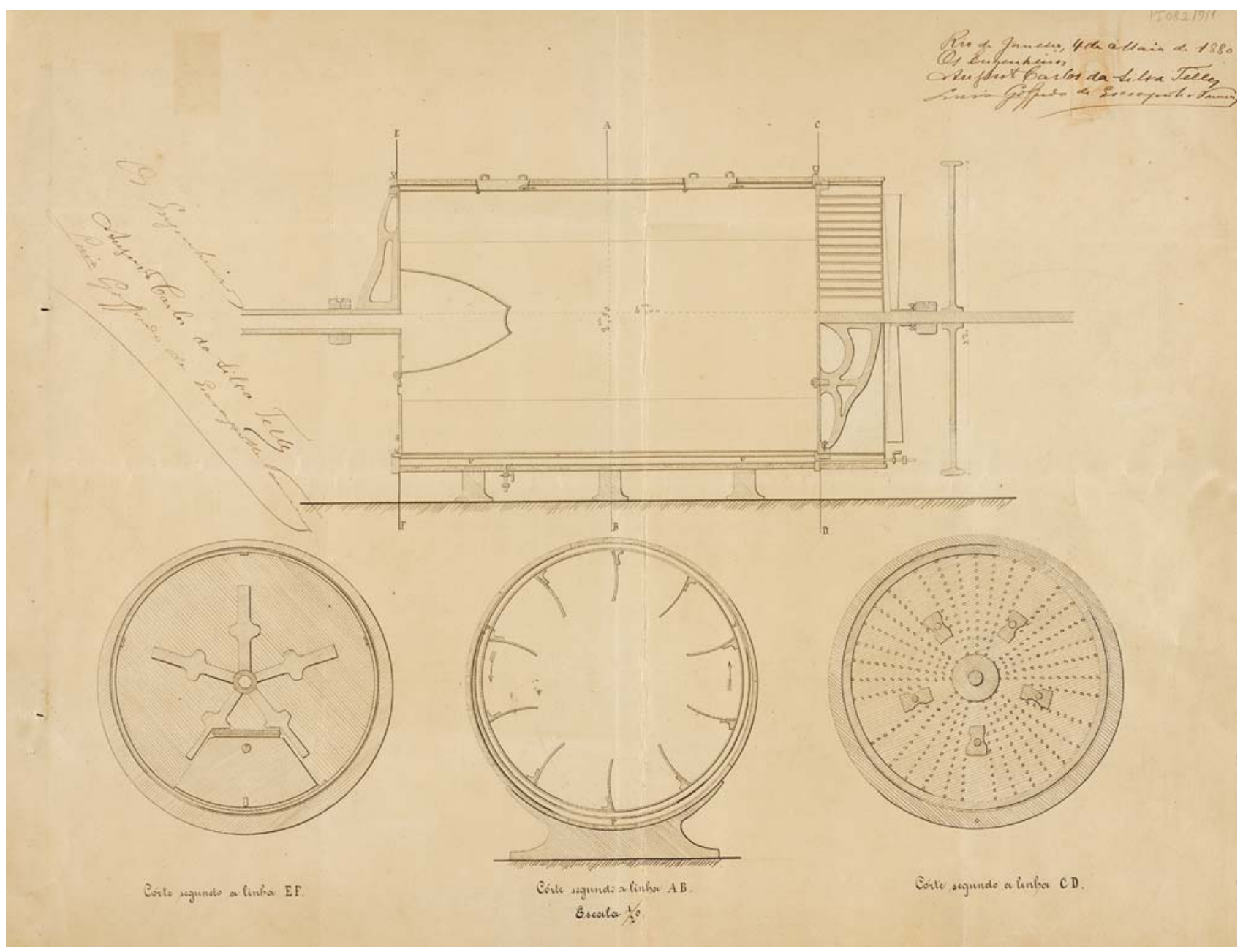

Figura 9 - Aspecto transversal da Machina de Seccar Café Taunay-Telles, 4 de maio de 1880. Acervo do Arquivo Nacional, Rio de Janeiro.

[...] Imprime-se movimento rapido à hélice de aspiração e ao ventilador; estabelece-se 80. Idem corrente energica de ar. Posto em movimento o cylindro interior, o café que occupa a parte inferior, é elevado pelas alcatruzes e, attingida certa altura, cahe atravessando a corrente de ar e cedendo-lhe parte de sua humidade. Todos os grãos passam pelos mesmos phenomenos veses sem conta; com vigor mathematico póde-se asseverar que com o grão $n$ se dará o mesmo que com o grão 1 .

[...] Na nossa machina, dá-se o seccamento como na natureza, pelo calor irradiado de uma fonte calorífera e a evaporação provocada pela renovação constante do ar saturado (grifo do inventor) $)^{80}$.

A intenção original dos inventores era reduzir a mão-de-obra empregada no beneficiamento, além de tornar a secagem do café independente 


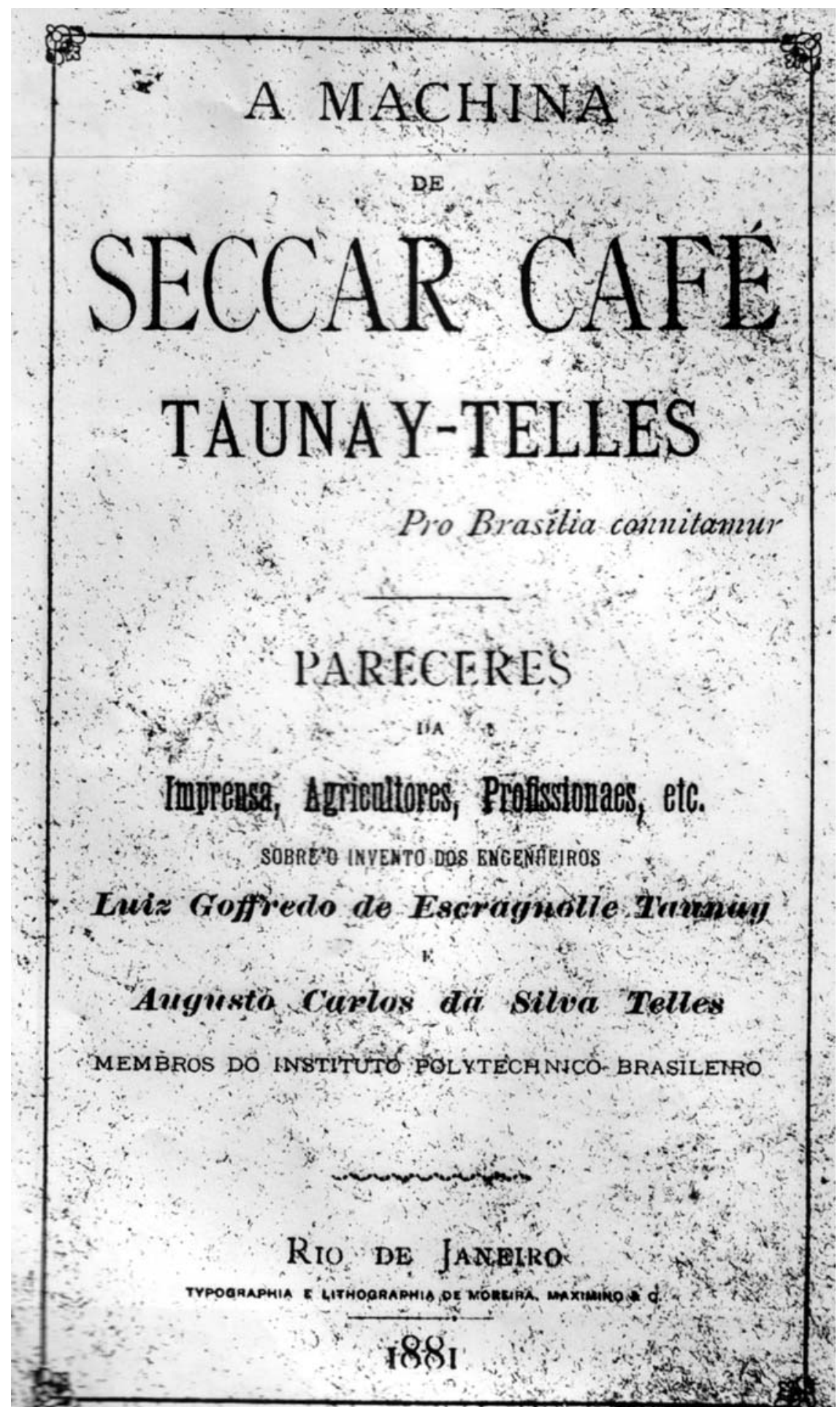

Figura 10 - Panfleto de divulgação Machina de Seccar Café Taunay-Telles, com pareceres, 1881. Acervo do Arquivo Nacional, Rio de Janeiro. 


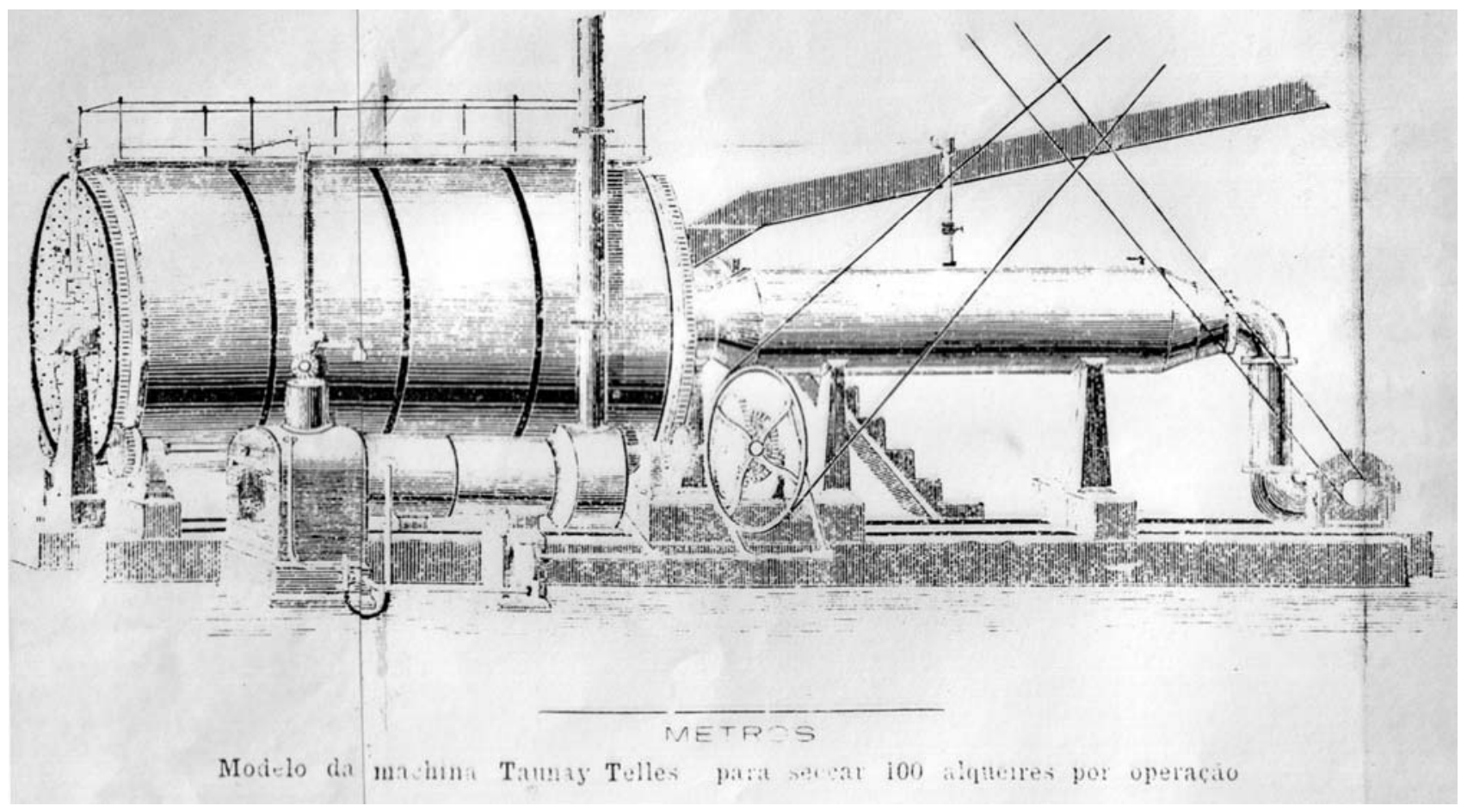

Figura 11 - Aspecto geral da Machina de Seccar Café Taunay-Telles para operar com 100 alqueires de café, 1881. Acervo do Arquivo Nacional, Rio de Janeiro.

das condições atmosféricas, sem preocupação em reduzir grandemente o tempo gasto na operação de secagem. Para desenvolver seu invento, analisaram várias máquinas em utilização, principalmente no Ceilão, onde eram produzidos os cafés mais conceituados do mundo. O maior problema estava na escala de produção, uma vez que as melhores máquinas e processos aplicados no exterior não atendiam ao volume das safras de café do Brasil, país que detinha cerca de $50 \%$ da produção mundial.

No entender de Louis Couty, o volume da produção demandava soluções técnicas que promovessem o homogeneização do beneficiamento:

[...] por vezes o café das camadas inferiores esta torrado até e o das superiores não apresenta o menor phenomeno de seccamento; outras, quando não há ventilação sufficiente, a umidade do café satura o ar e então os grãos aquecidos nesse meio amolecem, cozinham, ficam negros e sem aroma $^{81}$.

Couty saudou com entusiasmo a invenção de Taunay e Telles, por julgar que naquele momento a secagem do café era a única operação de preparação do produto que ainda não estava totalmente sob o controle do fazendeiro brasileiro. Devido a isso
81. O AUXILIADOR..., 1880. p. 201-206. 
82. O AUXILIADOR... 1880. p. 201-206

83. Idem. Ibidem.

84. ARQUIVO NACIONAL. PI-06819.

85. ARQUIVO NACIONAL. PI-06819.
[...] a necessidade de utilizar para esta operação o braço escravo, e de ficar inteiramente à mercê das condicões atmosféricas era uma das dificuldades mais consideráveis da produção do café no Brasil. Por causa desse único fator o fazendeiro não podia, de antemão, regular a sua colheita e contar até com o café colhido.[...]

Acontecia por vezes que o fazendeiro, urgido de mandar o seu café para o mercado, não podia seccá-lo bem, e por isso vendia-o em más condicões, imperfeitamente sêcco e dificilmente conservável.

Acontecia quasi sempre que uma só parte do café, o primeiro colhido, podia ser despolpado e dar o café lavado, que alcança maior preço, pois as cerejas, conservadas muito tempo no pé por falta de espaço no terreiro para seccá-las, não podião ser mais despolpadas ${ }^{82}$.

Conhecedor da indústria agrícola européia, Couty analisava o desenvolvimento tecnológico das máquinas de beneficiamento de café a partir das dificuldades enfrentadas pelos fazendeiros. Por isso, exaltava a inovação de seus amigos, tomando-a como um passo decisivo na evolução que a indústria cafeeira brasileira experimentava.

A indústria agrícola acha-se, porem, bastante adiantada no Brasil para aceitar facilmente esse invento? Para mim é líquido que sim: confesso ter ficado surpreendido vendo e estudando, primeiro em S. Paulo e depois no Rio de Janeiro, os processos aperfeiçoados postos em prática para a preparação do café. Pensava encontrar por toda a parte meios primitivos de beneficiamento, sempre à mão-de-obra direto, sempre o escravo, e por toda a parte encontrei machinas das melhores e mais custosas. Todas as vezes que fôra possível substituir a mão de obra direta, muito imperfeita e cara, sobretudo no Brasil com os escravos, se o fizera, os fazendeiros tinham sabido não recuar ante os primeiros sacrifícios, depois largamente compensados pela diferença de custo de mão-de-obra e maior valia dos produtos ${ }^{83}$.

Os estudos de concessões de patentes confirmam as impressões de Couty. Segundo Cruz e Tavares (1986, p. 21 8-219), entre 1830 e 1869 foram concedidas apenas treze patentes de privilégios industriais a inventores ligados ao café. No entanto, entre 1870 e 1882, as concessões de patentes para máquinas de beneficiamento de café inventadas ou aperfeiçoadas sob a lei de 1830 tiveram um aumento substancial do número de registros. As petições feitas no Rio de Janeiro - província e Corte - atingiram 65, 1\%; São Paulo registrou $30,2 \%$ e Minas Gerais 4,7\%, de um total de 43 patentes concedidas. É significativo que o primeiro registro tenha surgido em 1876, iniciando um movimento crescente de petições nos anos próximos a 1880, já que a lavoura cafeeira expandia-se por todo o Sudeste brasileiro, o preço do escravo encarecia e a campanha abolicionista ganhava mais vulto.

Voltanto às invenções de Taunay e Telles, em 1881 eles patentearam um aperfeiçoamento para o "[...] typo de seccador já privilegiado pelo Governo Imperial, modificado e melhorado em certas partes" ${ }^{\prime \prime 4}$. Para eles,

A inovação mais notável é a de dois planos inclinados introduzidos no cylindro movel. Esses planos são aquecidos pelo vapor de água circulando em tubos dispostos symetricamente entre duas placas metallicas. [...] $\bigcirc$ café é obrigado, por essa modificação, a correr pelos planos antes de cahir na parte inferior do cylindro móvel ${ }^{85}$. 
Tanto este melhoramento quanto o invento original foram criticados pelos próprios autores, devido ao custo elevado, mas eles estavam convencidos de que sua máquina havia atingido um grau de excelência. Assim, no requerimento para o "typo aperfeiçoado da Machina Taunay-Telles", afirmaram: "[...] suprimimos as caldeiras fixas e as substituímos por uma série de tubos de asas [...] que fornecendo o mesmo número de calorias que se obtinha a princípio tão dispendiosamente, são mais maneiros, occupão menos espaço e sobretudo são muito menos caros" 86 (grifo do autor).

Logo, o secador Taunay-Telles recebeu encomendas de fabricação do Dr. Braz Nogueira da Gama, da Fazenda Santa Luiza, que já utilizava máquinas Lidgerwood; e de Domingos Theodoro de Azevedo Júnior, grande fazendeiro de Santa Tereza de Valença. É possível que essas encomendas tenham estimulado outras, que, por sua vez, contribuíram para animar os inventores. Uma vez mais, é Couty quem explica o método da criação do novo secador:

[...] feitas experiências altamente satisfatórias em um modelo de dimensões reduzidas, construído no Rio de Janeiro resolveram [...] ir à Europa. Em Paris não descansaram; durante os primeiros meses de sua estada aí, visitaram manufaturas de tabaco, fábricas de pólvora, fécula, papel e outras em que podiam encontrar aparelhos de secagem e ventilação destinados a fim análogo ao que se propunham. Consultaram também especialistas, entre eles o ilustre Tresca, colhendo de tudo a convicção de só haver ligeiras modificações a introduzir no seu invento.

Completo o projeto definitivo da máquina tratou-se de construíla. Ainda aí os Drs. Taunay e Telles nada quiseram deixar ao acaso, e, posto tivessem a maior confiança na fábrica, tão justamente apreciada, do Sr. Guilherme Lidgerwood, foram em pessoa, por duas vezes à Escócia, e aí se demoraram algum tempo, afim de poderem acompanhar a construção em todas as minúcias ${ }^{87}$.

E continua, mostrando que os autores tinham em mente um objetivo bem definido a alcançar:

[...] Não se tratava simplesmente de secar o café; esse objetivo já fora conseguido pelo terreiro, pelas estufas e alguns aparelhos aplicados no Brasil e outros países. Impunham-se novas necessidades. A máquina definitiva devia conservar ao produto todas as suas propriedades, reduzir bastante o tempo antes gasto no terreiro, economizar mão-de-obra, despesas de instalação e manutenção, ser de fácil manejo, e, ao mesmo tempo, poder secar a enorme produção anual de uma fazenda ${ }^{88}$.

E Couty dá, ainda, uma idéia da problemática tecnológica que estava por ser superada na nova máquina (Figura 12):

[...] Os primeiros ensaios tinham feito reconhecer a utilidade de um tipo de máquina que realizasse as condições verificadas empiricamente boas pelo terreiro. Era, porém, indispensável dispor as superfícies de aquecimento em espaço limitado e calculá-las de modo a evaporarem a grande quantidade de água contida em 100 alqueires de café, e isto sem que o número de calorias transmitidas pudesse absolutamente estragar o produto; determinar o número de metros cúbicos de ar a introduzir na máquina para ser toda a umidade dissolvida e acarretada; combinar a temperatura do ar de modo a não ir este
86. ARQUIVO NACIONAL. PI-07548.

87. O AUXILIADOR..., 1883. p. 35-39.

88. Idem. Ibidem 

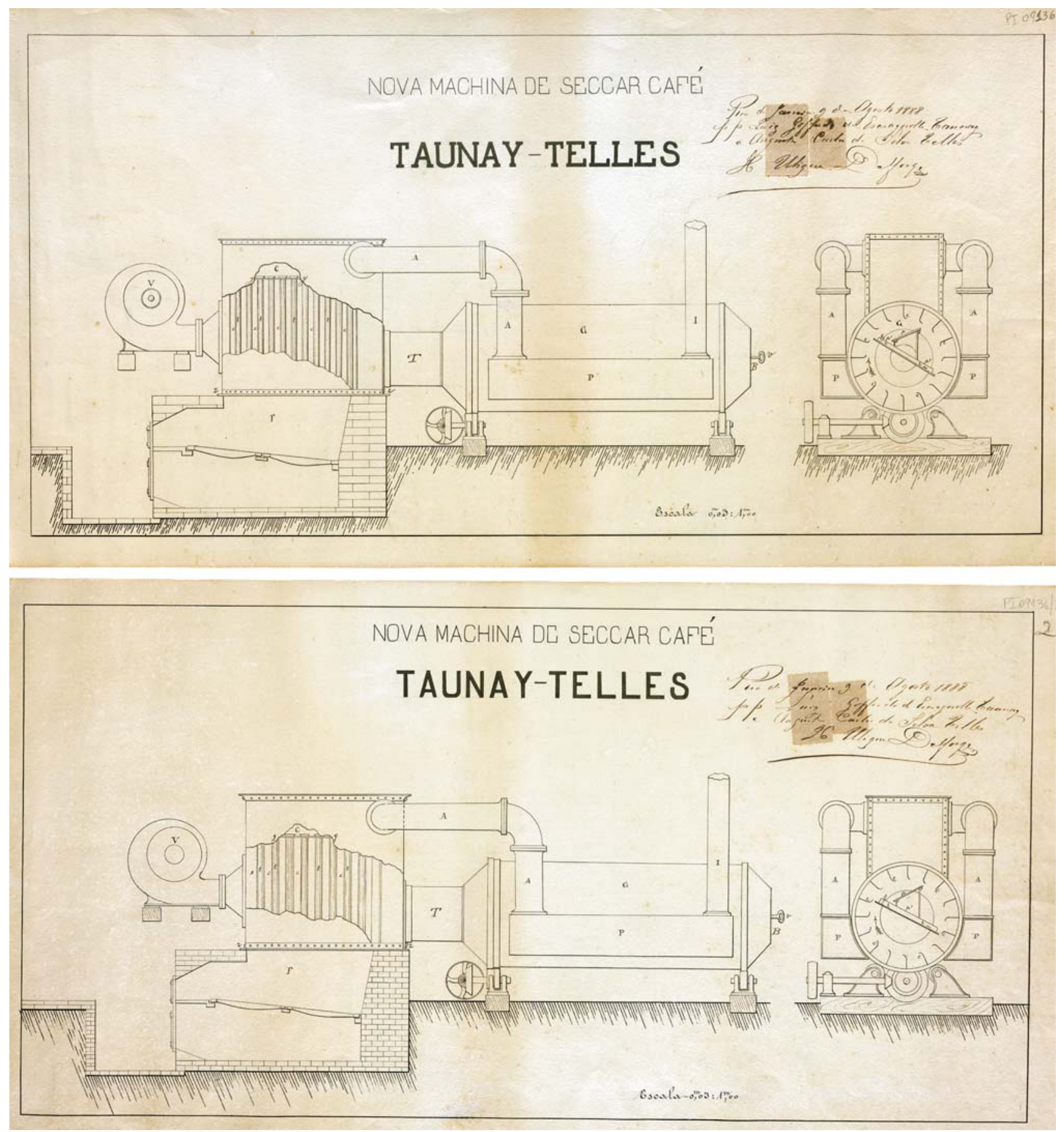

Figura 12 - Aspecto longitudinal e transversal da Nova Machina de Seccar Café Taunay-Telles, 1881. Acervo do Arquivo Nacional, Rio de Janeiro. 
roubar demasiado calor às superfícies aquecidas; dispor o interior da máquina, afim de estar o café sujeito a constante revolvimento, passando todos os grãos pela mesma série de fenômenos...

Era mister, ainda mais, tornar impossível o embolamento das massas na primeira fase da operação e o quebramento da cápsula córnea na última. Em uma palavra, satisfazer ao sem número de fatores físicos e mecânicos de um problema desesperadoramente complexo ${ }^{89}$.

Até aqui se buscou apresentar o quadro tecnológico que respondia pela resolução dos problemas relacionados às principais fases do benefício das grandes safras de café brasileiras. Contudo, outras questões relacionadas à popularização do consumo e ao conhecimento sobre o comportamento físicoquímico do produto, principalmente os destinados à sua decocção, desembocaram no desenvolvimento de novos equipamentos e processos de fabricação.

O primeiro deles foi a Cafeteira Fluminense, desenvolvida por José Antonio Antunes, cujo privilégio industrial foi concedido pelo Governo Imperial em 1875. Esta cafeteira obteve sucesso enorme e larga difusão, chegando a ser premiada na Exposição Nacional de 1875 e na Exposição Universal de Philadelphia, Estados Unidos, em 187690. Em sua fábrica, na rua Gonçalves Dias, no 39, na Corte, J. A. Antunes fabricava também peças avulsas de reposição e prestava assistência técnica. As vendas eram realizadas à rua da Alfândega, nº 78, no depósito da fábrica ${ }^{91}$. Somente em 1887, Antunes voltou a requerer privilégio industrial, dessa vez para "aperfeiçoamentos em cafeteiras denominadas fluminenses" 1 .

Outro equipamento ligado a uma melhor qualidade da colheita foi o Aparelho para Colher Café, criado por Manoel Francisco de Castro Nascimento. Funcionando como uma rede sob o cafeeiro, esse aparelho era utilizado durante a colheita para que o café não caísse no solo, evitando que grãos de terra e corpos estranhos se misturassem ao produto.

Para despertar o interesse por seu invento, Castro Nascimento mandou fabricar algumas unidades na Inglaterra e distribuiu-as entre fazendeiros conhecidos, afirmando-lhes que, com 100 homens disponíveis, necessitariam de 20 aparelhos para reduzir à metade o tempo da colheita. A estratégia funcionou e, conforme noticiou a Gazeta de Notícias, ao menos 20 unidades foram encomendadas ${ }^{93}$.

De acordo com a Lei de Patentes de 1830, os fabricantes estrangeiros não podiam patentear no Brasil inventos protegidos em outras nações. $\bigcirc$ reconhecimento dos direitos do estrangeiro expressava-se no prêmio que o inventor recebia a título de ressarcimento pela introdução de seu invento no país. Após este pagamento ser feito pelo governo, a patente se tornava de domínio público. Entretanto, a lei não esclarecia sobre o procedimento a ser adotado para as máquinas estrangeiras importadas para ○ Brasil. Pela prática adotada, ○ representante do fabricante estrangeiro no Brasil obrigava-se a requerer ao governo a concessão de privilégio exclusivo para proceder à importação e à venda de máquinas.
89. Idem. Ibidem. Em 1886, Taunay e Telles voltaram a patentear "melhoramentos introduzidos na machina" (ARQUIVO NACIONAL. PI07470). Em 1888, patentearam uma "nova machina de seccar café" com o mesmo nome da anterior (ARQUIVO NACIONAL. PI-09136).

90. Cf. Jornal do Commercio, Rio de Janeiro, p. 8,30 maio 1878 . O processo de PI não foi localizado. É muito provável que este invento corresponda ao que, no Brasil, atualmente é conhecido por Cafeteira Italiana.

91. Idem. Ibidem.

92. ARQUIVO NACIONAL. PI-00285

93. Embora o processo de privilégio e o decreto de concessão do privilégio não tenham sido localizados, vários anúncios informavam que o autor contava com o privilégio exclusivo da lei, a exemplo da publicação no Jornal do Commercio, Rio de Janeiro, p. 8, 23 fev. 1879. 
94. O AUXILIADOR.. 1870.p. 146. O processo de PI não foi localizado.

95. Idem. Ibidem.

96. O AUXILIADOR..., 1875. p. 340-341. Não foram localizados documentos de patenteamento da máquina Lidgerwood.
Nesse caso, também a SAIN era encarregada de apreciar a matéria. Na sessão de fevereiro de 1870, por exemplo, a assembléia dos sócios da SAIN acompanhou o parecer da Secção de Machinas e Apparelhos sobre o requerimento de José Gomes de Oliveira Guimarães para o privilégio de venda, por dez anos, das "Machinas de descascar, limpar, brunir e separar o café" de E. Carver \& Cia, de Boston, Estados Unidos ${ }^{94}$. O requerimento de Oliveira Guimarães foi negado, porque a invenção em questão já havia sido patenteada no Brasil, em abril de 1868, por Alberto Angell| ${ }^{95}$. Portanto, não poderia haver privilégio para a importação e venda de uma máquina estrangeira idêntica à que fora criada e patenteada no Brasil. Tal medida legal deve ter motivado alguns fabricantes estrangeiros a se estabelecer no país. Lidgerwood, já tratado anteriormente, era o fabricante que mais vendia máquinas no Brasil. No entanto, durante a década de 1860 e princípios da década seguinte, Lidgerwood adotou a nacionalização dos modelos mais necessários à lavoura cafeeira, consolidando seus produtos no mercado interno e protegendo suas máquinas de possíveis imitações, à medida que se popularizavam em todas as regiões cafeeiras.

Enquanto Guilherme Lidgerwood participava diretamente do núcleo de apreciação das invenções e melhoramentos que surgiam, suas máquinas serviam de parâmetro para o julgamento das novas patentes requeridas no Brasil. No início da década de 1880, o próprio André Rebouças lembrava que "Devemos a um filho da grande República, ao infatigável Engenheiro Mecânico - William Van Vleck Lidgerwood - a iniciativa de todos os melhoramentos introduzidos, nestes últimos anos, nos mecanismos de beneficiar café" (REBOUCCAS, 1883, p. 27).

Confirmando essa opinião, ao julgar a petição de privilégio de Manoel Rodrigues Alves Vianna para um aparelho capaz de "limpar e brunir" duzentas arrobas de café em um dia, a Secção de Machinas e Apparelhos ponderou que: "Entre as machinas de limpar e preparar café, usadas no Império, occupa o primeiro lugar a bem conhecida machina Lidgerwood, privilegiada até 1877 pelo Decreto no 5169 de 4 de Dezembro de 1872. Teve por isto a Secção o cuidado de examinar que a nova machina de brunir café não empregava os mesmos elementos mecanicos que a machina Lidgerwood" 96 .

Esta máquina de Lidgerwood deve ter tido sua patente requerida primeiramente no Brasil, para só depois ser reconhecida nos demais países. Mas não há certeza a este respeito. É possível ainda que William [Guilherme] Lidgerwood, como prática geral, introduzisse no Brasil suas inovações já patenteadas no exterior, recebendo por elas o prêmio correspondente, além de adquirir o direito de produzi-las no Brasil. Nesse caso, o fabricante ficava também com o direito a patentear os aperfeiçoamentos dessas máquinas no país. Isto se justificava porque o tamanho do mercado brasileiro compensava plenamente, por parte de Lidgerwood, a cessão, dos direitos de patenteador, para domínio público de algumas máquinas. Tal hipótese se fortalece à medida que, sendo máquinas de patente de domínio público, o fabricante continuava com o direito de seguir produzindo-as no Brasil. Para isso, contava com sua própria estrutura 
industrial e comercial, o que o colocava em posição de vantagem sobre a concorrência.

De qualquer maneira, no caso da patente de Lidgerwood referida pela Secção de Machinas e Apparelhos na apreciação do parecer de Alves Vianna, o tempo mínimo de privilégio que o fabricante inglês recebeu - 5 anos - sugere que havia interesse da Secção em reduzir a duração do tempo de privilégio do fabricante mais avançado, para que os direitos sobre a máquina caíssem mais rapidamente em domínio público, facilitando o patenteamento de similares e aperfeiçoamentos por outros inventores ${ }^{97}$.

Num outro requerimento de privilégios, desta vez para um limpador e brunidor de café, em 1875, a Secção elogiou os esforços dos inventores brasileiros para o aperfeiçoamento das operações de preparação do café exportável, por entendê-las da máxima urgência: "[...] os processos actualmente empregados são quasi os que nos legaram os tempos coloniaes: estão abaixo de qualquer crítica - todo o trabalho se faz a braços de pretos, que suffocão com o pó que sahe do café durante sua manipulação"98.

Julgando ainda a invenção de Alves Vianna, a Secção mostrou-se preocupada em evitar que a máquina em questão repetisse uma linha de brunidores que julgava superados.

Está muito em uso actualmente um brunidor de café, que consiste simplesmente em um grande cylindro, forrado com taboinhas de madeira pregadas com intervallos de um a dous centimetros. O café vai em saccos para o interior desse brunidor e é beneficiado pelo simples attrito de uns grãos sobre os outros durante a rotação desses cylindros.

Tem evidentemente esse apparelho o inconveniente de deixar o café com todo o pó e todas as matérias estranhas com que veio do terreiro; quando evidentemente o maior benefício, que se pode fazer é isolál-o de todas as materias estranhas ${ }^{99}$.

Ainda que reconhecesse ter havido a preocupação em dotar a máquina de capacidade de limpar e brunir o café, "a Secção recommendou-the que dê mais desenvolvimento a estas disposições de modo a obter simultaneamente para o café a melhor apparencia e o mais grato sabor" 100 . No caso deste autor, a Seção parecia particularmente interessada em estimular "[...] uma officina de machinas para lavoura na Barra do Pirahy em um centro importantissimo de cultura do café"101.

Tudo indica que tal postura da SAIN foi apropriada para que os inventores avançassem no desenvolvimento de tecnologia de beneficiamento do café. Uma década após, Manoel Rodrigues Alves Vianna \& Cia. era uma "officina de machinas para a lavoura, fundição de ferro e bronze" em Barra do Piraí, província do Rio de Janeiro, que produzia sob encomenda, além do brunidor privilegiado, também despolpadores de café de quatro capacidades diferentes, de 25, 50, 60 e 80 alqueires de café por hora ${ }^{102}$.

A evolução das patentes - necessária devido aos requisitos da lavoura e aos obstáculos da Secção de Machinas e Apparelhos em repetir inventos de ponta já privilegiados - forçava, no Brasil, um caminho tecnológico próprio,
97. Devido à omissão da lei de 1830 quanto às formas de garantir os direitos de patentes estrangeiras, assumo neste trabalho que o reconhecimento, quando se explicitava, restringia-se à publicação de um decreto, quando particularmente solicitado pelo patenteador estrangeiro diretamente interessado, sem passar pelo crivo da SAIN.

98. O AUXILIADOR..., 1875. p. 448-449.

99. Idem. p. 340-341; e Jornal do Commercio, Rio de Janeiro, p. 3, 9 mar. 1886.

100. O AUXILIADOR..., 1875. p. 340-341.

101. Idem. Ibidem.

102. Jornal do Commercio, Rio de Janeiro, p.3, 9 mar. 1886. O processo de PI do despolpador de Manoel R.A.Vianna não foi localizado. 
103. Cf. OAUXILIADOR... 1876. p. 290-292. O processo de privilégio industrial não foi localizado.

104. A patente era para um " $[. .$.$] cylindro forrado$ com talagarça de arame de aço, e as molas rectangulares, com saliencias digiformes, elementos mecanicos que constituem a indiscutível superioridade das machinas Lidgerwood sobre todas as outras" (O AUXILIADOR...,1876,p. 290-292)

105. O AUXILIADOR..., 1876. p. 290-292

106. Idem. Ibidem.

107. O AUXILIADOR. 1876. p. 415

108. A Machina Feronia foi privilegiada pelo Decreto no 6604, de 04.07.1867 e cedida a Moreira Cunha \& C. Em novembro de 1877 o cessionário requereu privilégio para uma inovação a ela. Cf. O AUXILIADOR... 1877. p. 533. Os processos de privilégios do invento original e seu melhoramento não foram localizados.

109. Trata-se de um aperfeiçoamento da máquina Brazileira para descascar café, que lhe alterou também o nome original. $\mathrm{Cf}$. O AUXILIADOR... 1877. p. 160 . O processo de PI não foi localizado.

110. Cf.OAUXILIADOR.. 1877.p. 160 caracterizado por invenções originais e melhoramentos comprovadamente funcionais para as máquinas de beneficiar café.

Outro exemplo disso foi o requerimento feito por José Ribeiro da Silva, inventor do Concassor Ribeiro, que, também no ano de 1876, solicitou o privilégio industrial para uma máquina capaz de descascar e brunir o café, a que chamou Eureka $^{103}$. Essa máquina era o resultado das críticas e recomendações que a Secção fez ao concassor, que apenas descascava o café, sem bruni-lo. Sem poder usar o sistema Lidgerwood, que consistia nos mesmos mecanismos privilegiados cuja patente já tinha sido negada a Alberto Angell ${ }^{104}$, Ribeiro buscou alternativas, recorrendo, na Eureka, a "[...] superfícies elásticas para o descascamento ou quebrador de casca, como elle denomina, e reserva muito prudentemente a helice não elástica para o brunidor"105

Com esse artifício técnico, Ribeiro conseguiu o privilégio exclusivo para a Eureka, com a ressalva de que a máquina destinava-se apenas ao uso na "pequena lavoura"106. A estratégia de Ribeiro de evitar repetir invenções consagradas definiu uma opção tecnológica que foi seguida por outros inventores brasileiros que, auxiliados pelos pareceres da Secção de Machinas e Apparelhos da SAIN, tiveram a chance de desenvolver suas invenções e progredir como fabricantes. Como exemplo, em 1876, a Secção aprovou uma petição para privilégio por dez anos para uma "nova machina de preparar café", embora entendesse que o invento não era original, por pertencer ao tipo de máquinas "sem molas ou elementos elásticos, como o primitivo Concassor Ribeiro". Nesse particular, a tolerância da Secção foi inconfundível, ao entender que "É muito provável que o actual requerente depois de mais profundo conhecimento do assumpto, faça os mesmos aperfeiçoamentos que o mencionado inventor ${ }^{\prime \prime} 107$.

Ainda nos anos da década de 1870, era tamanha a profusão de inventos, principalmente descascadores e secadores, que gerou entre os fabricantes inúmeros conflitos a respeito da autoria das invenções e dos diretos de fabricá-las e comercializá-las. Em 1877, uma polêmica envolvia os inventores José Ribeiro da Silva (Concassor Ribeiro), Joaquim Ribeiro Pedroso Júnior ("maquina de limpar" café Feronia) ${ }^{108}$ e Bernardino Corrêa de Mattos (Machina Maravilha) ${ }^{109}$. Na época, as questões entre eles se agravaram a tal ponto, que a SAIN chegou a marcar uma assembléia especial para tratar do "[...] conflito entre os inventores das machinas de preparar café $[. . .]^{1110}$. Mais que um impedimento à inovação tecnológica, as disputas entre inventores e empreendedores, no sentido proposto por Schumpeter (1982), dão mostras das possibilidades abertas à mudança tecnológica pela economia cafeeira do Sudeste brasileiro, ainda que sob relações escravistas de produção. As unidades produtivas - fazendas escravistas e fazendas trabalhadas por colonos italianos - articulavam-se com as potencialidades do mercado externo, vindo a criar um ambiente propício para o estabelecimento dos inventores de máquinas de beneficiar café. Ou seja, homens cujo ofício era criar soluções tecnologicamente ajustadas ao estágio de desenvolvimento experimentado na Europa, porém, sob as condições e características da lavoura brasileira. Desta forma, a trajetória de invenções e 
patenteamentos, como a de Samuel Beaven, cidadão inglês residente em Jundiaí, São Paulo, mereceria um estudo à parte. Autor isolado de mais de vinte patenteamentos de máquinas do trato do café, Beaven é o melhor representante dos inventores.

Ainda em 1876, a Secção de Machinas e Apparelhos protestou contra o autor ter apresentado, a um só tempo, petição de privilégio para quatro de seus inventos: um aparelho para matar formigas, preocupação constante na lavoura insolada; um ralador de mandioca; um aparelho para extrair raízes, útil na limpa e preparação da terra para o plantio; e um despolpador e descascador de café. Apesar do protesto, Beaven obteve os privilégios requeridos ${ }^{111}$.

Em seguida, a Secção concedeu a Beaven outro privilégio para "um aperfeiçoamento nas molas usadas pelas machinas de descascar café do systema de Lidgerwood". O autor também entrara na seara do fabricante mais renomado, criando a partir das máquinas melhor estabelecidas comercial e tecnologicamente. Nesse caso, o aperfeiçoamento parece ter sido bastante inovador. A Secção, sem ter como testá-lo, mas sem poder negá-lo de antemão, decidiu-se pela concessão do privilégio ao constatar que "[...]os princípios seguidos pelo inventor são racionais $[\ldots]^{\prime \prime 112}$.

A trajetória inventiva percorrida por Beaven demonstra tratar-se de um inventor profissional, detentor de grande saber técnico, muito articulado com os maiores fabricantes de máquinas de São Paulo. Em 1877, ele patenteava um aparelho que chamou Secador Horizontal de Beaven ${ }^{113}$; no ano seguinte, criava um "aparelho combinado" desse secador com um despolpador de café. A novidade consistia nas "[...]disposições de sua união com o despolpador." (Figura 13) 114.

Mas, em 1879, quando Beaven apresentou novo requerimento para esteiras de tela de arame para despolpar, descascar ou secar café, "[...] reconheceu a Seção que as esteiras, a que se refere o recorrente, são já muito conhecidas e aplicadas, com certas modificações, em maquinas de beneficiar café, já privilegiadas pelo Governo Imperial"115.

Por isso, a Secção deliberou contra conceder o privilégio e arquivou a petição do autor. No mesmo ano, Beaven tentaria patentear o Regulador Automático de Calor, segundo ele próprio um "apparelho de seccar e torrar café"116. Provavelmente, esse regulador seria uma melhoria no funcionamento do secador horizontal, podendo também ser utilizado em outros aparelhos. Em 1880, Beaven mais uma vez se faria presente para patentear uma máquina de despolpar café cereja ou descascar café seco - que chamou Despolpador Beaven ${ }^{117}$ ou Ventilador Beaven ou, ainda, Ventilador Ipanema ${ }^{118}$ - e um aparelho ventilador de café, a que chamou Limpador de Café Beaven ${ }^{119}$. $\bigcirc$ inventor também demonstrou pesquisar em profundidade a natureza físico-química do café e as necessidades da lavoura cafeeira do país. Nesse sentido, a respeito do despolpador apresentado, sugeriu os dez mandamentos de um bom aparelho desse tipo:
111. Cf.OAUXILIADOR... 1877.p. 85. Os processos de PI não foi localizado.

112. O AUXILIADOR... 1877. p. 486. O processo de PI não foi localizado.

113. Cf. O AUXILIADOR..., 1878. p. 122 e 147-148. O invento foi patenteado pelo Decreto ${ }^{\circ}$ 6711, de 13 de outubro de 1877. Seu processo de PI não foi localizado.

114. Idem. Ibidem.

115. O AUXILIADOR... 1879. p. 195 . O processo de PI não foi localizado.

116. ARQUIVO NACIONAL. PI-08179.

117. ARQUIVO NACIONAL. PI-08196.

118. Idem.

119. ARQUIVO NACIONAL. PI-08198. 


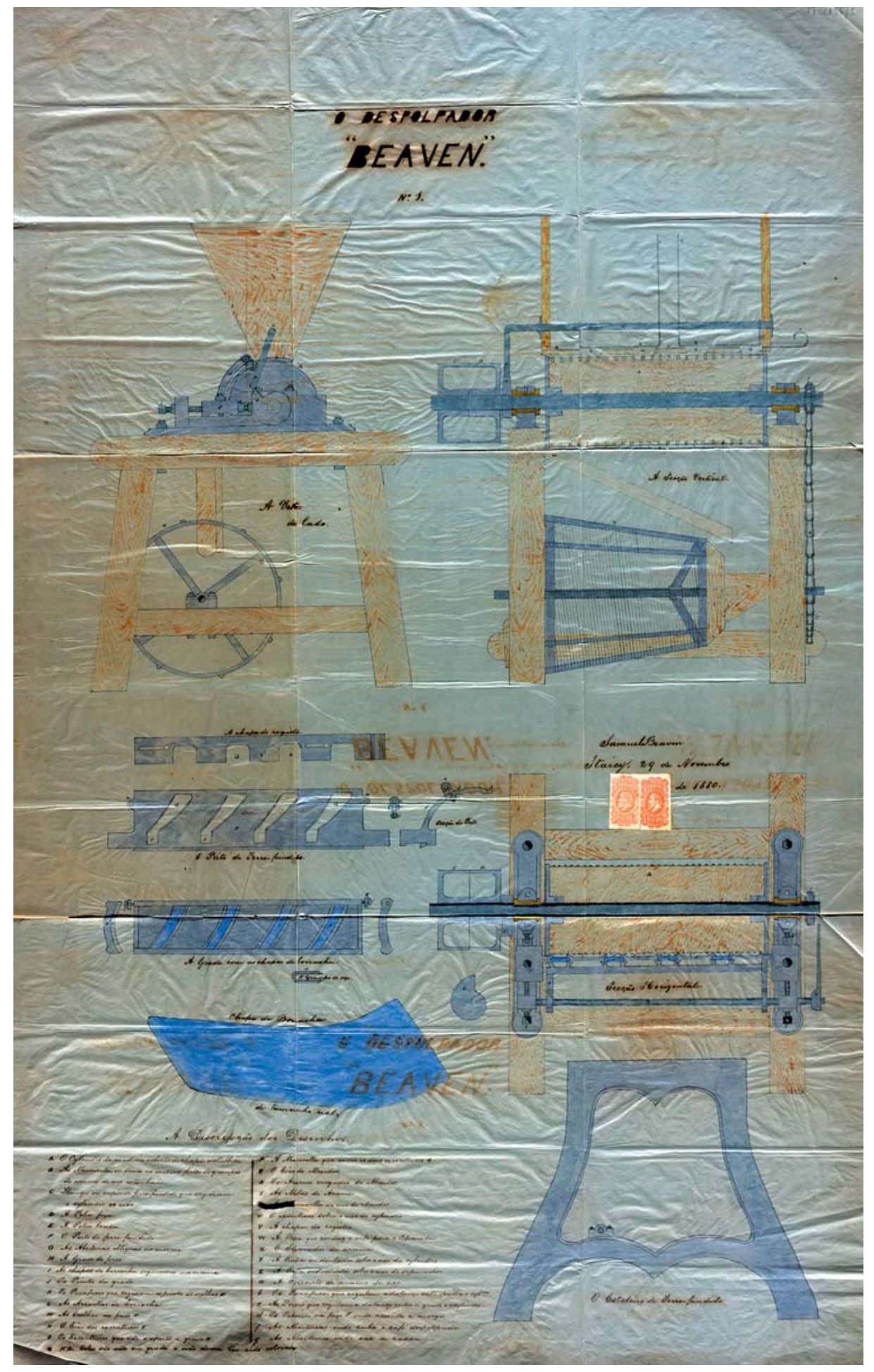

Figura 13 - Corte transversal das partes que compõem o Despolpador Beaven, 1880. Acervo do Arquivo Nacional, Rio de Janeiro. 
1. Deve tirar a casca vermelha sem prejudicar o pergaminho e a pellicula.

2. Deve separar a casca no processo de despolpar e não deixal-a misturada com o café para ser separada por outro processo.

3. Não deve deixar sahir um grão de café, junto com a casca.

4. Deve deixar passar todo o café verde sem ser despolpado, sendo impossível despolpar este sem tirar o pergaminho e a pellícula.

5. Deve ter meio de separar o café verde do despolpado.

6. Não deve entopir-se facilmente.

7. Deve ter meio de tirar facilmente qualquer cousa estranha que por acaso entra junto com o café.

8. Deve ter bastante duração e não ser dispendiosa em concertos.

9. Não deve carecer muita água nem grande força motora.

10. Deve ter preço razoavel ao alcance de todos os lavradores ${ }^{120}$.

No ano seguinte, Beaven voltou a patentear três invenções. A primeira era uma máquina multitarefa, que reunia as operações de descascamento, ventilação e separação do café, a que chamou Machina Beaven ${ }^{121}$. A segunda - uma demonstração de que o inventor percebia a necessidade de melhoria do café a partir das lavouras - era o Estrumador Ibicaba, "um apparelho destinado a espalhar estrume nos cafezais" ${ }^{\prime 22}$.

Quanto à terceira, tratava-se de um aperfeiçoamento do Despolpador de Gordon, uma máquina usada nas colônias inglesas da Ásia, e que tinha representado a Guatemala na exposição coletiva da América do Sul, dentro da Exposição Universal de Paris de $1878^{123}$. Ao mesmo tempo em que essa máquina era introduzida no Brasil, em 1880, Beaven já anunciava seu melhoramento, sob a alegação de que a máquina original, ainda que largamente utilizada no Ceilão, apresentava o inconveniente de quebrar os grãos que nela passavam. Por isso, procurou adaptar borrachas nas partes do aparelho que conduziam o café, além de outras mudanças que caracterizavam o melhoramento ${ }^{124}$. Esse patenteamento indica ter ocorrido um intercâmbio de informações, sobre as máquinas, entre os inventores e fabricantes do Brasil e os do exterior, como era a intenção da SAIN desde a sua fundação ${ }^{125}$. A estratégia da SAIN de melhorar inventos consagrados parece ter funcionado a contento, pois, da associação entre Beaven e Bierrembach, surgiu um despolpador que teve ótima aceitação nas fazendas. Segundo o fabricante de Campinas,

As machinas de despolpar café deste novo sistema em uso em diversas localidades, tem provado a sua superioridade, nos seguintes pontos:

1. O novo cylindro com os dentes feitos de grampos, evita a despeza continua de renovar as chapas

2. O novo systema de collocar e prender a borracha produz melhor resultado, e facilita tirar qualquer cousa estranha que por acaso entra junto com o café.

3. Separam perfeitamente bem a casca, o café verde, e o café despolpado limpo.

4. Occupam pequeno espaco, e o assentamento é facílimo.
120. ARQUIVO NACIONAL. PI-08196

121. ARQUIVO NACIONAL. PI-07733. O processo de PI não foi localizado.

122. Idem.

123. Cf O AUXILIADOR..., 1879. p. 36

124. ARQUIVO NACIONAL. PI-07732. A pesquisa não contemplou concessões de importação de máquinas para a comercialização, pois fugiria ao seu escopo.

125. A concessão de privilégio para o melhoramento no Despolpador Gordon foi obtida por Beaven pelo Decreto $\mathrm{n}^{\circ}$ 7755 , de 10 de julho de 1880. Não foi possível levantar, dentre os inventos patenteados por Beaven, quais foram fabricados $\mathrm{e}$ utilizados na lavoura e na indústria do café. Uma pesquisa com esse fim deverá consultar fontes de empresas industriais e comerciais de máquinas de café do período, além dos inventários de fazendas cafeicultoras. Alguns aperfeiçoamentos de suas máquinas feitos por outros autores permitem crer que as patentes de Beaven entraram, em grande parte, no circuito produtivo do café. 
126. Correio Paulistano São Paulo,p. 3, 2 fev. 1884

127. ARQUIVO NACIONAL. PI-08907. O processo de PI não não foi localizado.

128. ARQUIVO NACIONAL. PI-08948. É possível tratar-se do mesmo documento PI-08907.

129. ARQUIVO NACIONAL. PI-08950.

130. ARQUIVO NACIONAL. PI-00163.

131. ARQUIVO NACIONAL. PI-07409.

132. ARQUIVO NACIONAL. PI-08949.

133. ARQUIVO NACIONAL. PI-09215.

134. ARQUIVO NACIO NAL. PI-07412.

135. ARQUIVO NACIONAL. PI-00425.

136. ARQUIVO NACIONAL. PI-01028.

137. ARQUIVO NACIONAL. PI-01037.
5. Levam pouca força motora, e pouca água no serviço de despolpar.

6. São as mais singelas e as mais baratas.

Fazem-se os despolpadores de tres tamanhos para despolpar de 400 até 800 alq. (de 40 l[itros]) por dia ${ }^{126}$

A partir de 1883, já sob a legislação de privilégios industriais promulgada no ano anterior, Beaven daria continuidade à sua carreira tecnológica. Iniciando pelo Seccador Multitubular de Beaven ${ }^{127}$, desenvolveu ainda outro secador multitubular ${ }^{128}$ e, em 1884, uma Escolhedeira Beaven, para "escolher e limpar o café"129. A seguir patenteou uma outra máquina para "limpar e escolher café"130, a Escolhedeira Pneumática Beaven ${ }^{131}$ e o Despolpador Beaven Melhorado ${ }^{132}$, estes de 1885. Posteriormente, o inventor ainda patenteou o Seccador Beaven Melhorado (1888)133, um outro secador de café ${ }^{134}$ e uma máquina "para beneficiar café e arroz" (ambos em 1889)|135, um melhoramento da Machina de Despolpar Beaven ${ }^{136}$ e o Engenho de Café Beaven, uma máquina multitarefa para "limpar, descascar, ventilar, brunir e catar café, e de descascar arroz"(em 1890) $)^{137}$.

\section{Conclusão}

Este estudo pautou-se nos métodos da História para analisar o processo de formação de uma "matriz tecnológica" no Brasil. Tal processo iniciou-se na criação da Sociedade Auxiliadora da Indústria Nacional e na promulgação da Lei de Patentes de 1830, importantes marcos institucionais da fundação do Império, que, para a inovação tecnológica apontada, propiciaram a alteração do ambiente social até 1882, quando os interesses e valores culturais da economia agroexportadora cafeeira predominaram nas principais instituições nacionais e serviram-se da mecanização do benefício do café para atenuar as discrepâncias técnicas do trabalho manual e as contradições da utilização de mão-de-obra escrava no país, de forma que a economia cafeeira conseguisse atender à crescente demanda dos mercados internacionais.

Para colocar em questão a estrutura do complexo cafeeiro brasileiro a partir das transformações de sua base produtiva, tais como o crescimento da área plantada, a magnitude das safras exportadas e a utilização de mão-deobra escrava, do brasileiro livre e do imigrante - já tratados pela historiografia brasileira -, lançou-se mão de fontes ainda não examinadas pela historiografia, na expectiva de que fosse possível estabelecer as relações entre as instituições, a iniciativa dos inventores e empresários e, também, a demanda dos fazendeiros e agentes exportadores de café do Brasil e do exterior por inovações técnológicas.

Desta forma, a análise dos requerimentos de privilégios industriais de máquinas de beneficiar café encaminhados à Secção de Machinas e Apparelhos da Sociedade Auxiliadora da Indústria Nacional (SAIN) evidenciou um movimento pela inovação tecnológica com potencial suficiente para desenvolver uma indústria 
de máquinas de beneficiar o café, no Brasil, nas décadas de 1870 e 1880, capaz de atenuar as limitações do modelo escravista em vias de esfacelamento e equipar as fazendas produtoras.

Neste sentido, ao reunir as fontes iconográficas - produzidas pelos inventores/inovadores em suas patentes de invenção - com os anúncios publicados nos periódicos Correio Paulistano e no Jornal do Commercio, demonstra-se que a política de inovação tecnológica do Império produziu efetivamente uma modernização do beneficiamento das safras de café, ao gerar novos arranjos produtivos, baseados ainda, ao mesmo tempo, no reforço do suprimento de escravos negros e na colonização com imigrantes italianos, o que propiciou uma ampliação da área plantada e o aumento das colheitas a níveis sem precedentes.

Do ponto de vista político, a modernização do benefício do café encontrou na SAIN - com André Rebouças em seu período de atuação mais significativo - o espaço de legitimação técnica para as experiências advindas das lavouras e o abrigo para a maturação de um circuito de produção e comercialização de máquinas para as fazendas e engenhos de café. Graças à sua atuação crítica, a SAIN acabou por forjar um caminho tecnológico próprio, caracterizado pelo patenteamento de invenções originais e melhoramentos comprovadamente funcionais para as máquinas de beneficiar café nacionais ou mesmo para aquelas introduzidas via importação patrocinada pelo Estado, objetivando cópia e divulgação, o que acabou por estimular a concorrência de fabricantes estrangeiros que vieram estabelecer-se no país.

Expectativa do fim da escravidão? Conseqüência de uma legislação estimuladora do registro de patentes? Interesse no aproveitamento do potencial de crescimento da lavoura cafeeira? Facilidade de comunicação entre fabricantes e inventores de máquinas nacionais e estrangeiros? Genialidade criativa? $\bigcirc$ que se entende é que as fontes utilizadas e o caminho metodológico proposto bem revelam o potencial de novas pesquisas sobre a inovação tecnológica na economia escravista brasileira. Na verdade, são promissoras as abordagens do valioso acervo de privilégios industriais e pareceres técnicos da SAIN, para dar a entender o que teria feito Samuel Beaven e os outros autores aqui apresentados produzirem tantos inventos em menos de duas décadas, exatamente naqueles anos de maiores mudanças no quadro jurídico-institucional do Segundo Reinado.

Para além de atualizar uma problemática acerca das afinidades existentes entre a fazenda cafeeira escravista brasileira e a inovação tecnológica na segunda parte do século XIX, a contribuição que este artigo apresenta preliminarmente é o exame de fontes inéditas, tornando-as acessíveis aos historiadores. Abre-se, assim, um campo de estudos para a intensa produtividade dos inventores e a pronta absorção de suas máquinas no percurso da transformação na infra-estrutura da lavoura cafeeira às vésperas da Abolição e do golpe republicano. Neste sentido, Beaven e seus pares encarnaram a transplantação do saber técnico para a geração de tecnologia de máquinas de beneficiamento de café no Brasil. Ao transpor o modelo industrial europeu para o local da produção escravista do café, o Governo Imperial, os fazendeiros e os inventores de máquinas 
implantaram o padrão tecnológico que impulsionaria a agricultura cafeeira do país. Sujeitos da exitosa modernização da fazenda cafeeira, pelo movimento das máquinas, romperam-the a rotina e alteraram-the a dinâmica.

\section{REFERÊNCIAS}

ARQUIVO NACIONAL. Inventário Analítico ao Acervo de Privilégios Industriais. Rio de Janeiro, 1993.

BLOCH, M. "Advento e conquista do moinho d'água”. In: GAMA, R. (Org.). História da técnica e da tecnologia. São Paulo:T.A. Queiroz; Edusp, 1985, p. 59-87.

CAMARGO, R.;TELLES Jr., A. de Q. O café no Brasil: sua aclimação e industrialização. Rio de Janeiro: Serviço de Informação Agrícola; Ministério da Agricultura, 1953. 2 v.

COLLECÇÃO DAS LEIS DO IMPÉRIO DO BRAZIL DE 1830. Rio de Janeiro:Typographia Nacional, 1876.

CRUZ, H. N. ;TAVARES, M.A.R. As patentes brasileiras de 1830 a 1891. Estudos Econômicos, São Paulo, v.16, n.2, p. 205-225, maio-ago. 1986.

DUMONT, A. S. Os meus balões. Trad. A. de Miranda Bastos. [Rio de Janeiro?]: Biblioteca de Divulgação da Aeronáutica, 1938 (no original: Dans l'air).

FERNANDES, F. Mudanças sociais no Brasil. São Paulo: Difel, [1960].

HOBSBAWN, E. Da Revolução Industrial ao Imperialismo. Rio de Janeiro: Forense, 1983.

LANDES,D. S.Prometeu desacorrentado:transformação tecnológica e desenvolvimento industrial na Europa Ocidental, desde 1750 até a nossa época. São Paulo: Nova Fronteira, 1994.

LE BOT, M. Pintura y maquinismo. Madrid: Cátedra, 1979. cap. 2.

LOBO, E. et alli. Questão habitacional e o movimento operário. Rio de Janeiro: Editora da Universidade Federal do Rio de Janeiro, 1989.

KATINSKY, J. A invenção da máquina a vapor. São Paulo: Faculdade de Arquitetura e Urbanismo da Universidade de São Paulo, 1976.

KEMP, T. Grã-Bretanha 1870-1914: um pioneiro sob pressão. In: A revolução industrial na Europa no século XIX. Lisboa: Edições 70, 1987. Cap. 7.

LIMA, S. L. L. O Oeste Paulista e a Repúplica. São Paulo:Vértice, 1986.

O AUXILIADOR DA INDÚSTRIA NACIONAL. Rio de Janeiro: Sociedade Auxiliadora da Indústria Nacional, 1870-1883. 
PESAVENTO, S. Acertar o passo com a História: o dilema da modernidade brasileira no século XIX. In: Congreso Latinoamericano de História de la Ciência y de la Tecnologia, 3.: conferência. Ciudad de México: 1992.

REBOUÇAS, A. Agricultura nacional: estudos econômicos. Rio de Janeiro: Typographia A. J. Lamoreux, 1883.

RIBEIRO, L. C. M. Ofício criador: invento e patente de máquina de beneficiar café no Brasil (19701910). 1995. Dissertação (Mestrado em História)-Faculdade de Filosofia,Letras e Ciências Humanas da Universidade de São Paulo, São Paulo, 1995. 282 p.

SCHUMPETER, J.A. Teoria do desenvolvimento econômico. São Paulo:Abril, 1982.

SILVA, J. L. W. A SAIN (1827-1904) na formação social brasileira: isto é o que me parece. Dissertação (Mestrado em História)-Instituto de Ciências Humanas e Filosofia, Universidade Federal Fluminense, Rio de Janeiro, 1977.2 v.

TRUZZI, O. Café e Indústria: São Carlos: 1850-1950. São Carlos: Universidade Federal de São Carlos, 1986.

VASCONCELLOS, B. Archivo nobiliarchico brasileiro. Lausanne: Imprimerie La Concorde, 1918.

VON TSCHUDI, J. J. Viagem às províncias do Rio de Janeiro e São Paulo. São Paulo: Martins, 1954 (Biblioteca Histórica Paulista, 5).

WHATELY, M.C. O café em Resende no século XIX. Rio de Janeiro:José Olympio, 1987.

Artigo apresentado em 04/2006. Aprovado em 05/2006. 